\title{
Use of DOE Site Selection Criteria for Screening Low-Level Waste Disposal Sites on the Oak Ridge Reservation
}

D. W. Lee

R. H. Ketelle

L. H. Stinton

OPERATED BY

UNION CARBIDE CORPORATION FOR THE UNITED STATES DEPARTMENT OF ENERGY

\section{OAK \\ RIDGE \\ NATIONAL \\ LABORATORY}

\section{UNION}




\section{DISCLAIMER}

This report was prepared as an account of work sponsored by an agency of the United States Government. Neither the United States Government nor any agency Thereof, nor any of their employees, makes any warranty, express or implied, or assumes any legal liability or responsibility for the accuracy, completeness, or usefulness of any information, apparatus, product, or process disclosed, or represents that its use would not infringe privately owned rights. Reference herein to any specific commercial product, process, or service by trade name, trademark, manufacturer, or otherwise does not necessarily constitute or imply its endorsement, recommendation, or favoring by the United States Government or any agency thereof. The views and opinions of authors expressed herein do not necessarily state or reflect those of the United States Government or any agency thereof. 


\section{DISCLAIMER}

Portions of this document may be illegible in electronic image products. Images are produced from the best available original document. 


\section{The following pages are an exact representation of what is in the original document folder.}




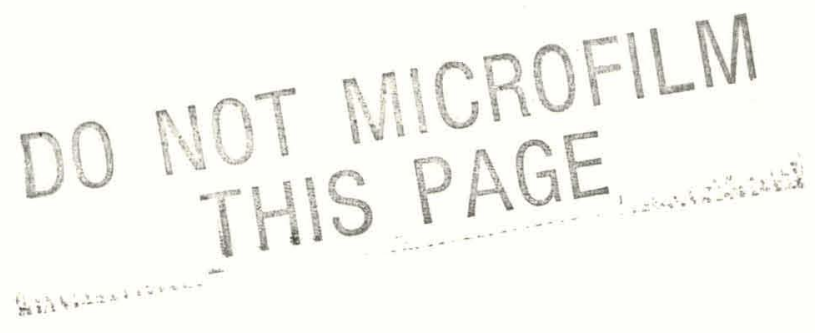

\author{
Printed in the United States of America. Available from \\ National Technical Information Service \\ U.S. Department of Commerce \\ 5285 Port Royal Road, Springfield, Virginia 22161 \\ NTIS price codes-Printed Copy: \\ Microfiche A01
}

This report was prepared as an account of work sponsored by an agency of the United States Government Neither the United States Government nor any agency thereof nor any of their employees, makes any warranty, express or implied, or assumes any legal liability or responsibility for the accuracy. completeness. or usefulness of any information, apparatus, product or process disclosed, or represents that its use would not infringe privately owned rights. Reference herein in any snecific commercial product. process, or service by trade name, trademark. manufacturer, or otherwise, does not necessarily constitute or imply its endorsement, recommendation, or favoring by the United States Government or any agency thereof. The views and opinions of authors expressed herein do not necessarily state or reflect those of the United States Government or any agency' thereof 
USE OF DOE SITE SELECTION CRITERIA

FOR SCREENING LOW-LEVEL WASTE DISPOSAL

SITES ON THE OAK BIDGE RESERVATION

D. W. Lee

R. H. Ketelle

ENERGY DIVISION

L. H. Stinton

UCC-ND/ENGINEERING
ORNL/TM- -8717

DE83 017992

Date Published - September 1983

\section{MOTICE}

PORTOONS OF TḦHS REPGRT ARE ULEGERE. lo has been reproducad from the thest available copy to permit the broadest possible availability.

Prepared by the

OAK RIDGE NATIONAL LABORATORY

Oak Ridge, Tennessee 37830

operated by

UNION CARBIDE CORPORATION

for the

Low-Level Waste Management Program

U.S. DEPARTMENT OF ENERGY

under Contract No. W-7405-eng-26

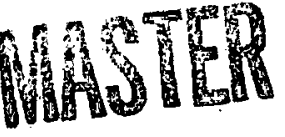




\section{DISCLAIMER}

This report was prepared as an account of work sponsored by an agency of the United States Government. Neither the United States Government nor any agency thcrcof, nor any of their employees, makes any warranty, express or implied, or, assumes any legal liability or responsibility for the accuracy, completeness, or usefulness of any information, apparatus, product, or process disclosed, or represents that its use would not infringe privately owned rights. Reference herein to any specihc commèrelal product, provess, ur selvice by tiadi name, tradomark, manufacturer, or otherwise does not necessarily constitute or imply its cndorsement, recommendation, or favoring by the United States Government or any agency thereof. The views and opinions of authors expressed herein do uul ieciessarily statc or refloct those of the United States Government or any agonoy thereof. 
LIST OF TABLES

LIST OF FIGURES vii

ABSTRACT $\quad$ ix

EXECUTIVE SUMMARY

1. INTRODUCTION $: 1-1$

1.1 Background 1-1

1.2 Scope 1-2

1.3 Site selection procedures 1-3

1.3.1 Site selection strategies - 1-3

1.3.2 DOE site selection criteria 1-5

2. GENERIC METHODOLOGY FOR APPLICATION OF SITE SELECTION CRITERIA

2.1 Site screening 2-1

2.1.1 Region definition 2-3

2.1.2 Candidate area identification 2-3

2.1.3 Candidate site identification 2-5

2.1.4 Preferred site identification 2-7

2.2 Site characterization 2-12

2.2.1 Site feasibility investigation 2-14

2.2.2 Field investigation 2-16

2.2.3 Laboratory investigation 2-16

$\begin{array}{ll}2.2 .4 & \text { Monitoring prograin } \\ 2.17 & \end{array}$

$\begin{array}{ll}2.2 .5 & \text { Pathways analys is } \\ & 2-17\end{array}$

3. APPLICATION OF THE SITE SELECTION CRITERIA USING THE GENERIC METHODOLOGY

3.1 Candidate area identification 3-1

3.2 Candidate site identification 3-2

3.3 Preferred site identification 3-6

3.4 Comparison with previous studies 3-21 
4. CONCLUSIONS AND RECOMMENDATIONS

4-1

4.1 Criteria evaluation

4-1

4.2 Application of DOE site selection criteria

$4-2$

4.3 Recommendations for use of the generic methodology $4-3$

4.4 Conclusions

1-5 


$$
\text { v } 10 i
$$

\section{LIST OF TABLES}

Page

Table 1.1 Draft DOE site selection criteria

Table 1.2 Performance objectives for disposal system operations to protect the health and safety of workers and the public

Table 2.1 Site selection parameters for identification of the preferred site

Table 2.2 An example worksheet for comparing candidate sites on the basis of a single site selection parameter

Table 3.1 Candidate area screening requirements for the Oak Ridge Reservation

Table 3.2 Candidate areas and potential sites within candidate areas

Table 3.3 Candidate site screening requirements for the Oak Ridge Reservation

Table 3.4 Candidate sites within the 0ak Ridge Reservation

Table 3.5 Comparison of sites - hydrology 3-10

Table 3.6 Comparison of sites - geology 3-11

Table 3.7 Comparison of sites - soil 3-13

Table 3.8 Comparison of sites - 1 and use 3=14

Table 3.9 Comparison of sites - socioeconomics 3-15

Table 3.10 Comparison of sites - ecological and meteorological 3-16

Table 3.11 Ranking of sites for site selection parameters 3-18

Table 3.12 Sumnary of results - overall ranking 3-20 
viij V(I)

\section{LIST OF FIGURES}

Page

Figure 2.1 Summary of site selection methodology 2-2

Figure 2.2 Candidate area identification 2-4

Figure 2.3 Methodology for candidate site identification 2-6

Figure 2.4 Methodology for preferred site identification 2-8

Figure 2.5 Methodology for site characterization 2-13

Figure 2.6 Environmental pathways for release of radioactivity from low-level waste disposal facilities 2-18

Figure 3.1 Candidate areas on the 0ak Ridge Reservation 3-4

Figure 3.2 Candidate sites on the 0ak Ridge Reservation 3-8 


\section{ABSTRACT}

The proposed Department of Energy (DOE) site selection criteria were applied to the Oak Ridge Reservation, and the application was evaluated to determine the criteria's usefulness in the selection of a low-level waste disposal site. The application of the criteria required the development of a methodology to provide a framework for evaluation. The methodology is composed of site screening and site characterization stages. The site screening stage relies on reconnaissance data to identify a preferred site capable of satisfying the site selection criteria. The site characterization stage relies on a detailed site investigation to determine site acceptability. The site selection criteria were applied to the DOE Oak Ridge Reservation through the site screening stage. Results of this application were similar to those of a previous siting study on the Oak Ridge Reservation. The DOE site selection criteria when coupled with the methodology that was developed were easily applied and would be adaptable to any region of interest. 


\section{EXECUTIVE SUMMARY}

This study applied the proposed Department of Energy (DOE) site selection criteria (Draft DOE Order 5820, Sept. 10, 1982) to the Oak Ridge Reservation to evaluate their ease of application and to identify any difficulties arising during their application. For application of the criteria to site selection, a methodology was developed to provide a framework for evalaution.

Site selection is considered a two-stage process: site screening and site characterization. Site screening relies on reconnaissance data for identification of a preferred site, and site characterization relies on a detailed site investigation and analys is for evaluation of the site's capability to comply with the DOE performance objectives. The procedure used for. site selection incorporates DOE site selection criteria, the needs of the developer, and the consideration of alternative sites. Performance assessment models were not used for site screening because of the extensive data needs that generally are not available.

The site screening methodology applies the DOE site selection criteria by defining a region of interest, identifying candidate areas. within the region of interest, identifying a slate of candidate sites within the candidate areas, and identifying a.preferred site from a slate of candidate sites. The region of interest is defined on the basis of the need for additional waste disposal facilities and must be large enough to include several candidate areas. Candidate areas are identified by eliminating areas having features that preclude them from further consideration. Candidate sites are identified by using exclusionary site requirements and identifying desirable site features. The exclusionary requirements, (e.g., a slope that does not exceed 25\%) are based on sitespecific factors derived from the DOE site selection criteria that would preclude utilization of the site for low-level waste disposal. Desirable features include disposal facility needs (e.g., the availability of utilities) that must be satisfied. The preferred site is identified by collecting and reviewing reconnaissance data. Site selection parameters are derived from the DOE site selection criteria for comparing candidate sites. For example, the site selection parameter of geology includes the 
DOE site selection criteria requiring that sites be located where geologic hazards will not jeopardize performance, sites be located where hydrogeologic conditions allow the subsurface migration of radioactivity to be reliably predicted, and buffer zones be designed in consideration of hydrogeologic characteristics. The ranking of the candidate sites for each site selection parameter is performed following the candidate site comparison. The composite of site rankings and the significance of each site selection parameter are used to identify the preferred site for site characterization. The preferred site should be the site which is best suited to the needs of the developer and which can satisfy the DOE site selection criteria.

The site characterization methodology includes a preliminary investigation of site feasibility, a comprehensive field study, a laboratory analysis of field samples, a site monitoring program, and a pathways analysis. The site feasibility study provides a preliminary concept of site utilization and performance and initiates the interaction of site design with other site characterization activities. The field investigation of the preferred site provides the necessary data for evaluation of site performance and for further site development. The 1 aboratory analysis of field samples interprets field data, confirms field observations, and assists in defining additional field activities. The monitoring program establishes background environmental data and determines seasonal variations In lhe environmental data. The pathways analysis determines if the preferred site can meet the DOE performance objectives. The pathways analys is may determine limitations on waste form and quantity or the need for additional monitoring activities; it may define additional design requirements for site acceptablity.

The DOE site selection criteria were applied through site screening to the Oak Ridge Reservation. The reservation was defined as the reyiun of interest with DOE as the developer. The limited size of the Oak Ridge Reservation admits only the Conasauga and Knox Groups as viable geologic groups for consideration because of the limited soll thickness associated with the remaining groups. Five candidate area screening requirements were developed that resulted in the identification of five candidate areas 
containing at: least one potential site in each area. Candidate site screening requirements were developed containing four. exclusionary requirements and five desirable features. Five candidate sites were identified, two sites in Bear Creek Valley and three sites on Chestnut Ridge. Site selection parameters for preferred site identification were developed as hydrology, geology, soils, land use, socioeconomics, and ecology/meteorology. Each criterion in the DOE site selection criteria is associated with at least one site selection parameter. For example, the criterion which states that new sites shall be located where hydrogeologic conditions allow subsurface migration of radioactivity to be reliably. predicted is associated with the hydrology, geology, and soils site selection parameters. Relative comparisons of the candidate sites for each site selection parameter were performed based on reconnaissance data. The candidate sites were ranked for each parameter and sumarized in an overall ranking of candidate sites. The results of the investigation did not identify a preferred site with natural features that makes it clearly the best site. Five sites were identified which potentially could satisfy the site selection criteria. The selection of the preferred site is best determined by consideration of other factors such as previous operating experience, costs of site development and detailed facility needs. Such an integrated process will allow for the selection of a preferred site that is best suited to the needs of the developer and capable of meeting the $D O E$ site selection criteria. The results of this study suggest that both Knox and Conasauga Group sites have deficiencies that detract from their suitability for low-level waste disposal and that must be addressed in the design of a low-level waste disposal facility. These results were similar to a previous siting investigation. The similarity suggests that the available technical information was similarly interpreted and applied; however, the present study more clearly documents and evaluates the comparative merits of each site.

The results of this study indicate that the DOE site selection criteria are useful in site selection and specifically in site screening. The criteria encompass the important factors to be considered in site selection; however, they are subject to interpretation and provide no 
guidance as to how they should be applied. When coupled with the methodology developed in ths study, the criteria were easily applied and would be adaptable to any region of interest.

Application of the DOE site selection criteria using the generic methodology is qualitative and requires considerable judgment at each step. The development of the screening requirements, site selection parameters, and the definition of the region of interest most strongly influenced the identification of a preferred site. Site deficiencies which require further consideration in the design of a facility were clearly identified as a result of using the site selection criterla fur identification of a preferred site. 


\section{INTRODUCTION}

The Department of Energy (DOE) has proposed site selection criteria* for identifying low-level waste disposal sites that would satisfy various performance objectives to protect public health and safety. Prior to this study, the usefulness of these criteria in site selection had not been evaluated. This section presents the criteria and the approach used to evaluate them for screening low-level waste disposal sites.

\subsection{Background}

Additional disposal facilities will be required to accommodate lowlevel radioactive wastes produced in the future. Developing the technology and documentation required to establish a shallow land burial site for low-level waste disposal is one of the goals of DOE's Low-Level Waste Management Program (LLWMP). DOE has prepared draft site selection criteria for low-level waste disposal. The primary purpose of this study was to apply the criteria and evaluate the usefulness of the site selection criteria for low-level waste disposal siting. The DOE site selection criteria are not intended to provide a process for site selection, but they do provide guidelines which are to be met at an acceptable site. The application of the site selection criteria, however, requires a methodology that is rational and defensible for selecting a site. An appropriate methodology that would facilitate the evaluation of the criteria was developed as part of the study. The site selection criteria were then applied to a specific region using the generic methodology.

The study was completed in four steps. The first step (Sect. 1.3) summarized site selection criteria and reviewed procedures for selecting shallow-land burial facilities for low-level radioactive waste. Necessary factors to be considered in the application of the site selection criteria were identified. The second step (Sect. 2) developed a generic methodology for applying the DOE site selection criteria to a region,

*Draft DOE Order 5820, dated Sept. 10, 1982. 
identifying candidate areas and sites, ranking candidate sites, identifying a preferred site, and evaluating a preferred site. The methodology was prepared to provide an operational framework for applying the DOE criteria. The third step (Sect. 3) applied the generic methodology to a specific region--the Oak Ridge Reservation. To determine the validity and usetulness of the application, the results were compared to a previous site selection study conducted for the reservation. The last step (Sect. 4) evaluated the usefulness of the site selection criteria and the generic methodology for other regions of interest.

\subsection{Scope}

The selection of a site is the first phase in a progression of events required to establish a new land disposal facility. It consists of two stages--site screening and detailed characterization of a preferred site. The site screening stage culminates in identification of a preferred site. Site screening is based primarily on reconnaissance information, including published or unpublished reports, existing records, and brief field surveys. Site characterization follows site screening and establishes whether or not the preferred site can meet the DOE criteria and performance standards. This stage requires a field program and detailed site investigation to collect site-specific data and is, therefore, much more time consuming and expensive than site screening. The DOE site selection criteria are critical to both site screening and site characterization. The methodology developed in this study considers both site screening and characterization and was prepared so that its application to future site selection investigations would be possible. The DOE criteria are applied only through the site screening stage for the 0ak Ridge Reservation because sufticient data are not yet available to apply the criteria for site characterization. The Oak Ridge Reservation provided an opportunity to evaluate the ease of application of the criteria because new disposal facilities are needed, and site data are available from both previous siting studies and ongoing site characterization programs for many locations on the reservation. 


\subsection{Site Selection Procedures}

The selection of a site for low-level waste disposal must satisfy $v$ arious site selection criteria and be suited to the needs of the developer. The developer in the case of defense wastes will be DOE or an operating contractor for DOE. The site that is selected must al so remain an acceptable choice for a site considering the viable alternative sites that could be selected. To identify a preferred site meeting all requirements, the application of the site selection criteria should be clear, the basis for identifying potential sites should be stated, and the judgments which lead to the selection of the site should be apparent. For the ease of application of the DOE site selection criteria to be tested realistically, the needs of a potential developer and the consideration of alternative sites are essential factors to be included in the study. The DOE site selection criteria by thenselves do not provide a means for selecting a site or satisfying these competing needs. To provide a realistic evaluation of the $D O E$ site selection criteria that considers alternative sites and the needs of a developer, a strategy for site selection is required.

\subsubsection{Site selection strategies}

Site selection strategies commonly are used to site major facilities.1-5 Generally, a region of interest is identified, important site selection parameters are developed using site selection criteria, data are collected, a sensitivity analysis is performed, and sites are evaluated. Most site screening processes are qualitative because of a lack of available data, differences in the interpretation of the criteria at a specific site or the assumptions and judgments imposed.

The evaluation of candidate sites is a comparison of site characteristics in either qualitative or quantitative terms. Although characteristics may be weighted and ranked quantitatively, the associated assumptions or judgments render these evaluation methods no more objective or valid than qualitative site comparisons. 
Low-level waste site selection in the past was not performed with the use of a consistent set of criteria or guides. The most prominent characteristics shared between the sites that were selected were the availability of land on or near a nuclear facility and government ownership of the 1 and .6 Limited attention was given to the investigation of the characteristics of a potential site that would determine its performance or stability. Al so, limited regulatory guidance was provided. As a result, performance-based site selection strategies . have not been developed and applied to disposal facilities that are presently operating. Recently, the International Atomic Energy Agency (IAEA) outlined an approach to low-level waste site selectlun sillilar to those commonly used at other major facilities. ${ }^{7}$ The approach calls for an area survey, preliminary site selection, and site confirmation. Details of this approach will to be provided in a forthcoming publication. 8

Computer codes for site selection applicable to low-level waste disposal facilities have been developed. These codes are not based on an analytic procedure or theory but revert to a decision tree or trade-off evaluation method. Many of the available codes are sumnarized in 'D-OW-Level Waste Management: A Compilation of Models and Monitoring"9 and "Modeling and Low-Level Waste Management: An Interagency Workshop."10 Specific models are also addressed in "System Analysis of Shallow Land Burial"11 and "Generic Methodology for Assessment of Radiation Doses from Groundwater Migration of Radionuclides in LWR Wastes in Shallow Land Burial Trenches." 12 The models may be useful at the site characterization stage, but the input data requirements are normally beyond the information available at the site screening stage. If these site characterization models were used at the site screening stage, many assumptions would be required to satisfy the data requirements liat would detract from the validity of the results. Additionally, the codes have not been developed for use with the DOE site selection criteria. Consequently, computer code results would have to be interpreted in light of the site selection criteria and are not well adapted to testing the ease of application of the DOE site selection criteria. 
Processes for selecting shallow land burial sites have been developed, although they have not been developed to the extent that could be easily applied to identify a specific site.13-14 Lacking an available site selection strategy for applying the DOE site selection criteria to select a site and evaluating the usefulness of the DOE site selection criteria, a methodology for using the criteria and addressing the developer's needs and alternative sites was formulated and used in this study. The methodology that was developed is sufficiently flexible that it could be applied to either the DOE or Nuclear Regulatory Comission (NRC) site selection criteria.

\subsubsection{DOE site selection criteria}

Site selection criteria for low-level waste disposal facilities have been proposed by DOE and developed by NRC.15-17 The DOE and NRC criteria are similar and somewhat qualitative and provide the minimum technical requirements necessary for a site to meet the performance objectives. This study demonstrates the application of proposed DOE criteria for disposal site selection, but the same methods can be used with any given set of criteria including NRC criteria. The DOE criteria to be applied in selecting a low-level waste disposal site are listed in Table 1.1. The first five criteria in Table 1.1 are related to the geohydrologic characteristics of the site. The effect of this emphasis significantly influences the site selection process. Performance objectives for land disposal of low-level radioactive wastes are sumarized in Table 1.2. 
Table 1.1. Draft DOE site selection criteria15

1. New sites shall be of sufficient size to include a waste disposal area, administrative area, and adequate buffer zone to allow unrestricted human use beyond the site boundary.

2. New sites shall be located so that wastes can be buried either completely above or completely below the transition zone between the unsaturated and saturated zones.

3. New sites shall be located where flooding, wind and water erosion, and geologic hazards such as earthquakes, volcanoes, and slides and mud flows do not jeujardize performance.

4. New sites shall be located where hydrogeologll curutitions allow subsurface migration of radioartivity. to be reliably predicted.

5. Buffer zones for new sites shall be designed in consideration of hydrogeologic characteristics so that radioactivity releases comply with the objective of this order.

6. New sites shall be selected with consideration given to current and projected population distributions, land use, and resource development; accessibility of all-weather highways, rail routes, and utilities; and the location of waste generators.

7. New sites shall be selected in compliance with applicable federal, state, and local laws and reyulations. 
Table 1.2. Performance objectives for disposal system operations to protect the health and safety of workers and the public 18

1. Every shallow land disposal site shall be operated in conformance with DOE occupational exposure standards

2. The annual dose from radionuclides from any shallow. land burial site to persons outside the site boundary from all pathways shall not exceed the following

$$
\begin{aligned}
& 25 \mathrm{mrem} / \text { year - whole body } \\
& 75 \mathrm{mrem} / \text { year - thyroid } \\
& 25 \mathrm{mrem} / \text { year - any organ }
\end{aligned}
$$

3. Waste shall not be disposed of in a shallow. land burial site that results in a waste inventory that poses a potential threat to health and safety after a performance period of 500 years has ended 
1. J. F. MCBrayer et al., "Identifying Alternatives at a Reconnaissance Level," EIA Review 2(2): 190-95 (1981).

2. Nuclear Regulatory Comission, Final Environmental Statement Related to Construction of Greene County Nuclear Power Plant, NUREG-0512, 1979.

3. Department of Energy, Final Environmental Impact Statement, Solvent Refined Coal-II Demonstration Project, DOE/EIS-0069, 1981.

4. Department of Energy, Final Environmental Impact Statement, Solvent Refined Coal-I Demonstration Project, D0E/EIS-0073, 1981.

5. Department of Energy, Final Environmental Impact Statement, Memphis Light, Gas and Water Division Industrial Fuel Gas Demonstration Project, DOE/EIS-0071, 1981.

6. G. L. Meyer, "EPA Views on Selection of Sites for Land Disposal of Low-Level Waste," in Vol. 1 of Proceedings of the Symposium on Low-Level Waste Uisposal, Site Suitabilily Requirements, NUREG/CP-0028, CUNr-811218, 1982.

7. International Atomic Energy Agency, Shallow Ground Disposal of Radioactive Wastes, A Guidebook, Safety Series No. 13, IAEA, Vienna, 1981 .

8. International Atomic Energy Agency, Site Investigations for Repositories for Solid Radioactive Wastes in Shallow Ground, IAEA, Vienna (in preparation).

9. Science Applications, Inc., Low Level Waste Management: A Compilation of Models and Monitoring Techniques, ORNL/SUB-79/13617/2, Oak Ridge, Tenn., 1980. 
10. Department of Energy, Modeling and Low Level Waste Management: An Interagency Workshop, OR0-821, Oak Ridge, Tenn., 1980.

11. Nuclear Regulatory Commission, System Analysis of Shallow Land Burial, NUREG/CR-1963, Science Applications, Inc., 1980.

12. Atomic Industrial Forum, Generic Methodology for Assessment of Radiation Doses from Groundwater Migration of Radionuclides in LWR Wastes in Shallow Land Burial Trenches, AIF/NESP-013, 1981.

13. Department of Energy, A Process for Locating Shallow Land Burial Sites for Low-Level Radioactive Waste, DOE/LLW-16T, 1983.

14. Department of Energy, Directions in Low-Level Waste Management The Siting Process: Establishing a Low-Level Waste Disposal Facility, DOE/LLW-6TC, 1982.

15. Department of Energy, "DOE Site Selection Criteria," DOE Manual, Chap. 5820 (Draft), Sept. 10, 1982.

16. Nuclear Regulatory Commission, "Licensing Requirements for Land Disposal of Radioactive Waste," 10 CFR Part 61, Fed. Regist. 47 (248): 57446-82, 1982.

17. Nuclear Regulatory Commission, Technical Position - Site Suitability, Selection, and Site Characterization, NUREG-0902, 1982.

18. Department of Energy, DOE Manual, Chap. 5820 (Draft), Aug. 8, 1982. 


\section{GENERIC METHODOLOGY FOR APPLICATION OF SITE SELECTION CRITERIA}

Site selection encompasses the screening of viable sites within a region for a preferred site and the characterization of the preferred site for evaluation of site acceptability. Site screening is an inherently qualitative process that requires the comparison of several site factors of varying importance to identify a preferred site. Careful application of the DOE criteria for low-level waste disposal sites can simplify licensing, reduce site development costs, and simplify postclosure surveillance and maintenance. This section presents a methodology for applying DOE site selection criteria to identify a preferred site from a defined region and to characterize the preferred site for evaluation and design. The criteria are applied using the methodology so that uncertainties in site identification are reduced and the probability of selecting an acceptable site for low-level waste disposal is enhanced.

\subsection{Site Screening}

The objective of site screening is to identify a preferred site for detailed site characterization. Site screening should identify a site that can be successfully characterized, modeled, analyzed, and monitored during the site characterization stage of site selection. Site screening is performed using reconnaissance-level data. A detailed discussion of these information needs and their method of acquisition is presented in the Shallow Land Burial Handbook. 1 The methodology used to apply the site selection criteria must be logical and defensible so that the preferred site identified by the process is best suited to the needs of the developer and will satisfy the regulatory requirements for low-level waste disposal. The methodology described in this section addresses these goals by defining a region of interest, identifying candidate areas within the region of interest, identifying a slate of candidate sites with in the candidate areas, and identifying a preferred site from the slate of candidate sites (Fig. 2.1). Each step in the site screening process uses 


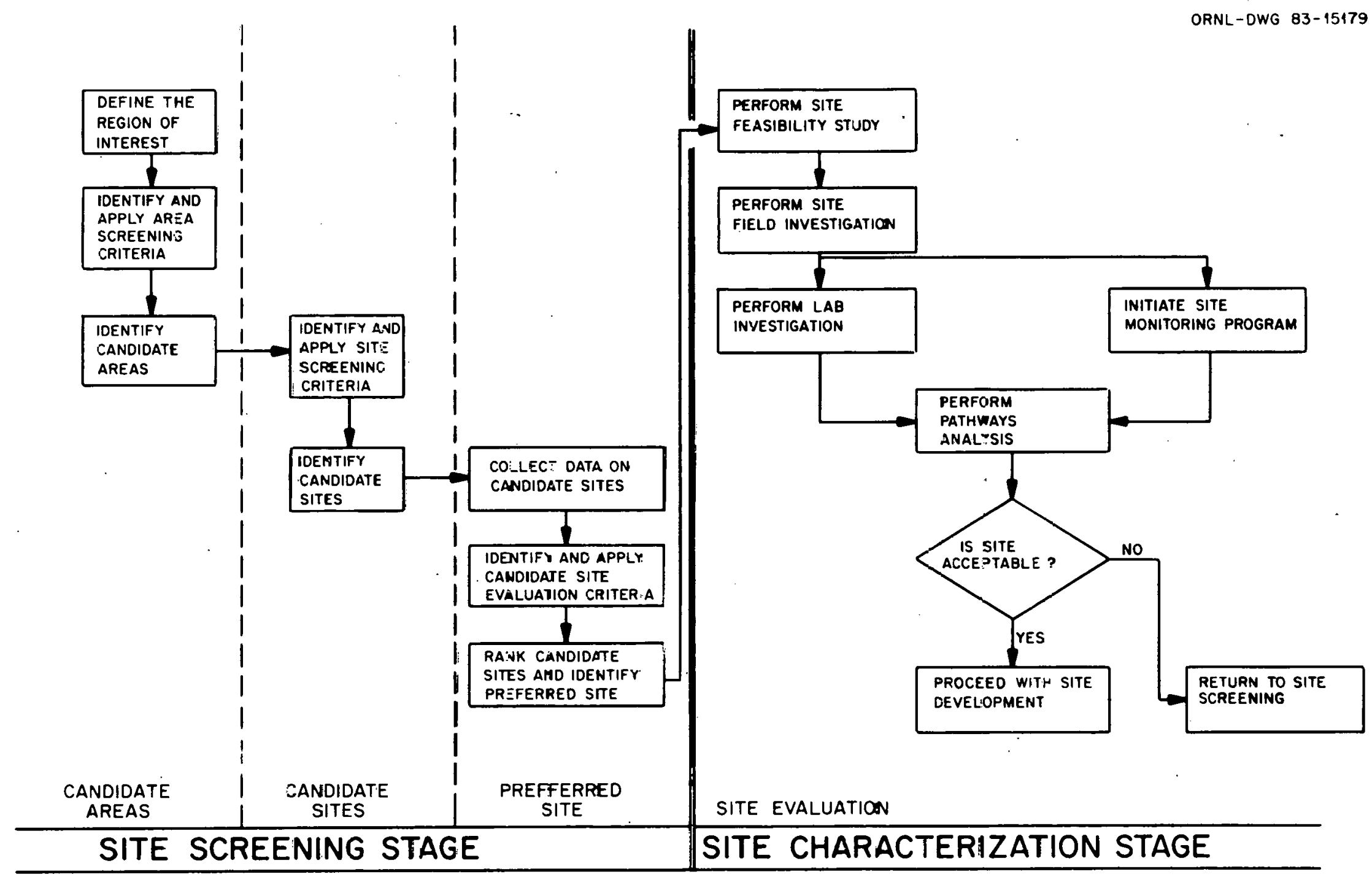

$\stackrel{\sim}{n}$

Fig. 2.1. Summary of site selectior: methodology. 
progressively more restrictive criteria based on the developer's needs and the DOE site selection criteria (Table 1.1). Documentation of each step in the process is an important component of the methodology to provide a logical and defensible basis for identifying a preferred site.

\subsubsection{Region definition}

The definition of the region of interest is the first step in site screening. The region is defined on the basis of need for additional low-level waste disposal facilities to service waste generators. The region may be defined as a compact of states, a state, a DOE reservation, or some other geographical unit. Independent of the need for additional waste disposal facilities, the region of interest must be large enough in size to include several candidate areas with at least one candidate site within each candidate area for a reasonable comparison of potential sites. If the region of interest is too narrowly defined, the potential for identifying an acceptable site is reduced.

\subsubsection{Candidate area identification}

The methodology for identifying candidate areas in a defined region of interest is shown in Fig. 2.2. The first step in the identification of candidate areas is to determine area screening requirements. The area screening requirements are exclusionary requirements that eliminate areas having features that precilude them from further consideration. These requirements should be based on the essential needs for facility development, such as sufficient land area and gross geological and hydrological requirements and the site selection criteria that can be applied to an area. (An example of candidate area screening requirements for a specific region is presented in Table 3.1.) The area screening requirements are used to identify the areas within the region of interest having the fewest obvious deficiencies that would inhibit site development. Consequently, the requirements are somewhat arbitrary and should be tightened or relaxed until a reasonable number of candidate areas are identified. The number 
ORNL-OWG 83-15188

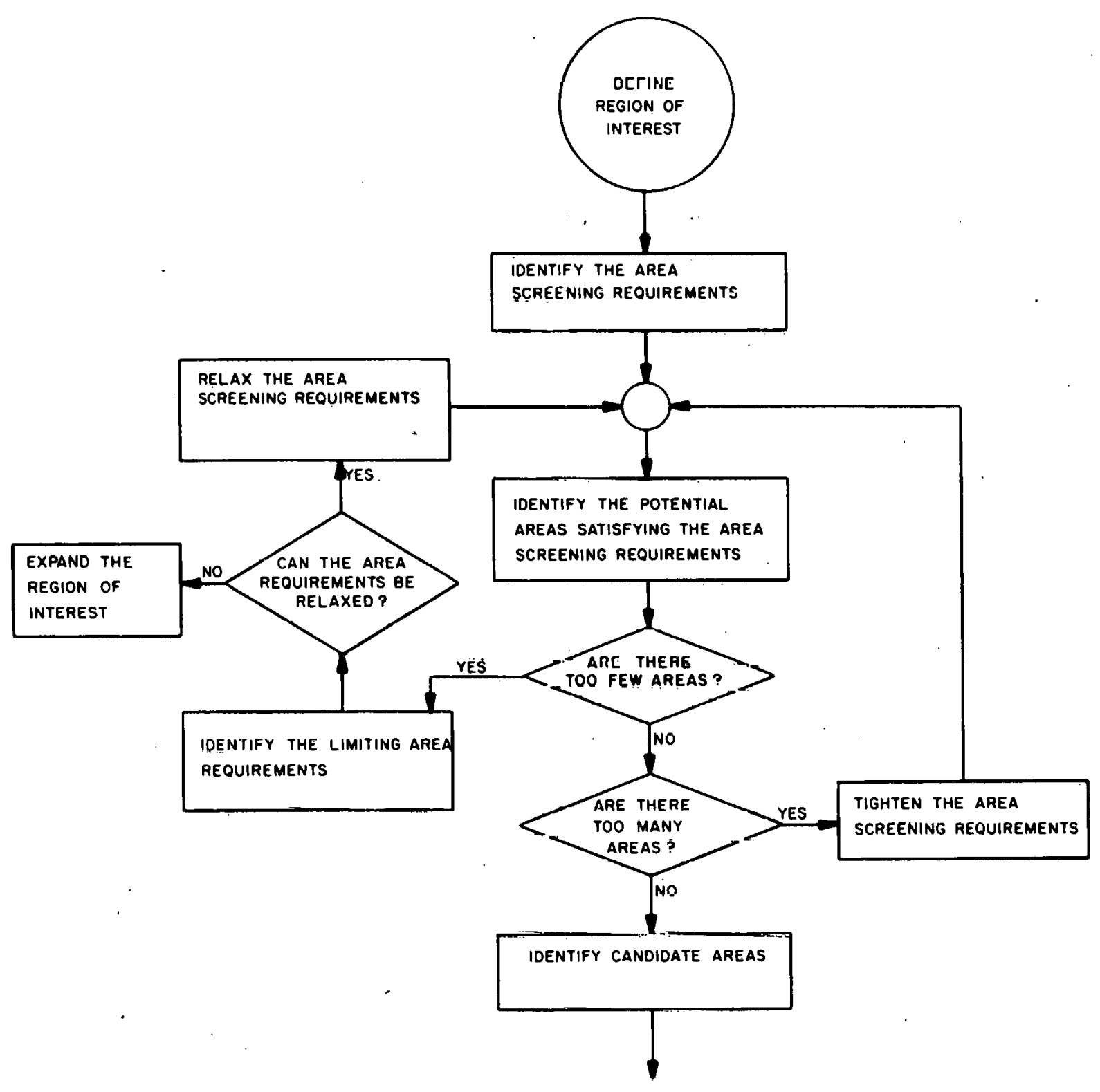

Fig. 2.2. Candidate area identification. 
of areas will vary from region to region. The goal is to have enough candidate areás for identifying a sufficient number of candidate sites to conduct a valid site comparison incorporating regional variability. The candidate areas that are identified and the area screening requirements used for identification should be documented prior to proceeding to candidate site identification.

\subsubsection{Candidate site identification}

The methodology for identifying candidate sites within established candidate areas is shown in Fig. 2.3. The first step in the identification of candidate sites is to identify site screening requirements. Site screening requirements include exclusionary requirements and features that are desirable for a site. The exclusionary requirements should be based on site-specific factors developed from the DOE site selection criteria which would preclude utilization for low-level waste disposal (for example, excessive slope or the presence of wetlands). Desirable features to be included in the site screening requirements could include facility.: needs, such as the proximity to utilities or other site conditions derived from the DOE site selection criteria. (An example of candidate site screening requirements for a specific region is presented in Table 3.3.) Site screening requirements are used to identify the sites within the candidate areas that have the greatest potential as waste disposal sites and represent the regional variability within the candidate areas. As with the area screening requirements, site screening requirements are somewhat arbitrary and should be tightened or relaxed until a reasonable number of candidate sites remain. If relaxation of the site screening requirements fails to produce a sufficient number of candidate sites, then the area screening requirements should be relaxed or the region of interest expanded. Once the slate of candidate sites has been identified, the site screening requirements and the results of the site screening should be documented. 


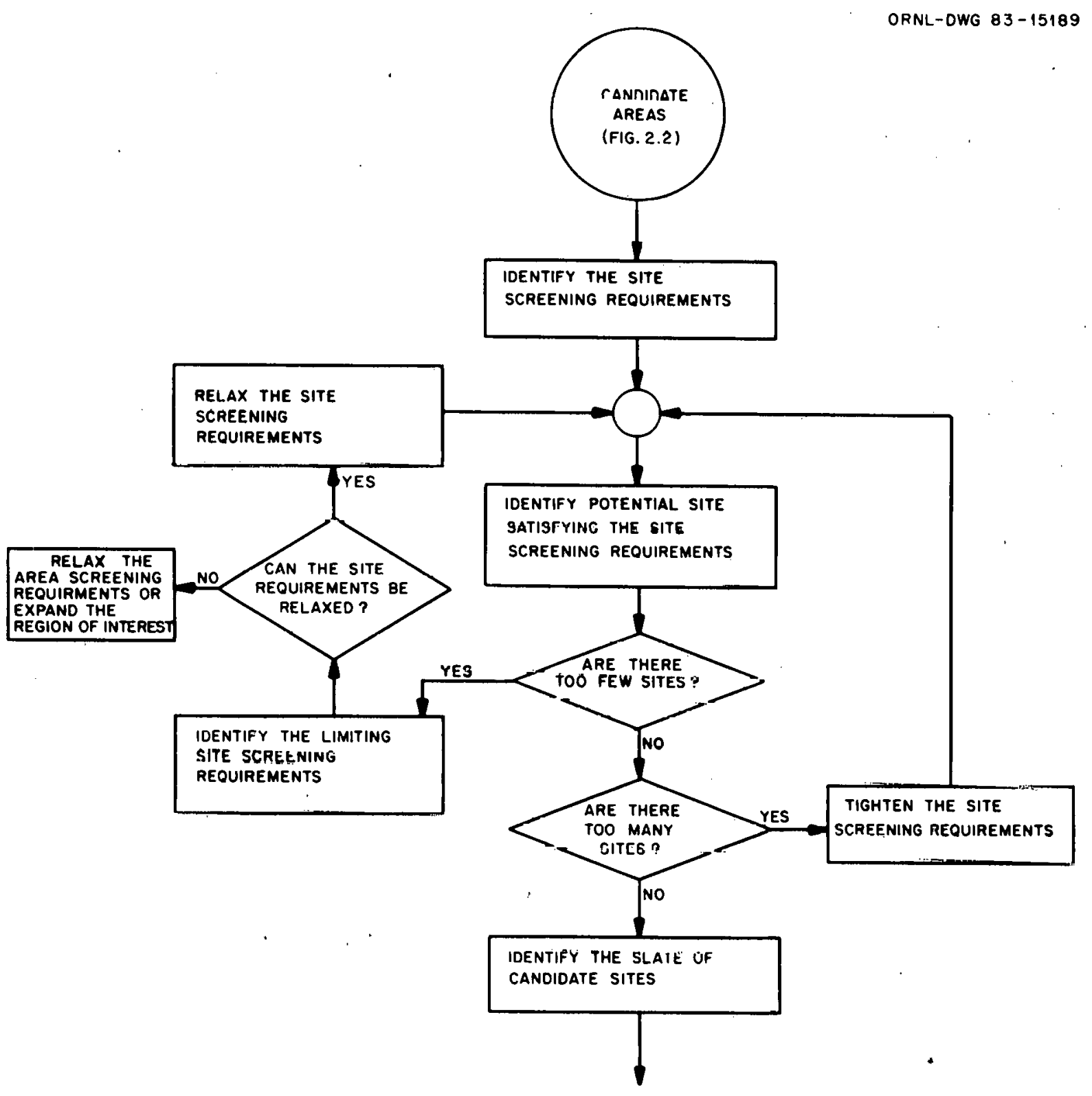

Fig. 2.3. Methodology for candidate site identification. 


\subsubsection{Preferred site identification}

The methodology for identifying a preferred site for an established slate of candidate sites is shown in Fig. 2.4. All available data on each of the candidate sites are gathered and reviewed from existing sources and from site reconnaissance. Site reconnaissance does not include detailed field studies but provides for field inspection of the existing environmental conditions.

The site selection parameters are developed from DOE site selection criteria and regional factors. The site selection parameters should be identified with consideration of the significance of the most important regional factors and their disciplinary groups. An example of site selection parameters is shown in Table 2.1 along with the parameters' relationship to the DOE site selection criteria. As can be seen in Table 2.1, the criteria are biased towards the geohydrologic characteristics of the site. The significance of each site selection parameter for the region of interest is determined based on available data and subjective evaluation. This step is critical to the ultimate results since the selection of parameters and assigninent of relative significance influence which site is designated as the preferred site.

The candidate sites are ranked for identification of the preferred site using a comparative matrix for each parameter. A single parameter is selected and the comparative superiority or inferiority of one site to another relative to the parameter is determined. Each site is judged to be better, the same, or worse than the other candidate sites for each parameter, based on the available information. An example worksheet for evaluation of a single parameter is shown in Table 2.2. The ranking of the candidate sites for each parameter is established by ordering the sites from highest to lowest rank. The composite of site rankings and significance for all of the parameters is examined to identify the preferred site (Table 2.1). This last step in the site screening analys is may be subjective and may not result in a definitive conclusion. The top-ranked site may be roughly equivalent to the second-ranked site. In such cases, the preferred site may be determined by the interests of the 
COLLECT DATA ON THE SLATE OF GANDIDATE SITES

SLATE OF

CANDIDATE

SITES

(FIG. 2.3)

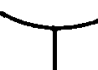

LIT

IDENTIFY THE DOE SITE SELECTION PARAMETERS OF INTEREST

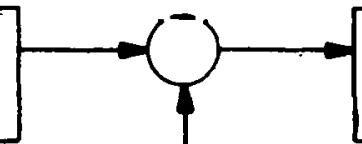

IDENTIFY OVERALL RANKING OF THE CAHDIDATE MITES

IOENTIFY THE PREFERRED SITE

Fig. 2.4. Methodnlngy for preferred site identification.

EVALUATE THE SIGNIFILANCE Ü A SELECTED PARAMETER

EVALUATE DATA AVAILABLE FROM THE CANDIDATE SITES RELATIVE TO THE PARAMETER OF INTEREST

COMPARE THE RELATIVE PERFORMANCE OF THE CANDIDATE SITES TO THE PARAMETER OF INTEREST (BETTER, SAME, OR WORSE)

COMPARATIVELY RANK THE CANDIDATE SITES FOR THE PARAMETER OF INTEREST

No ARE ALL HARAMETERS ANALYZED?

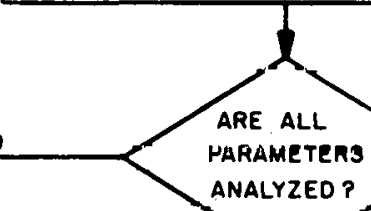

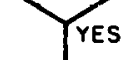


Table 2.1 Site selection parameters for identification of the preferred site

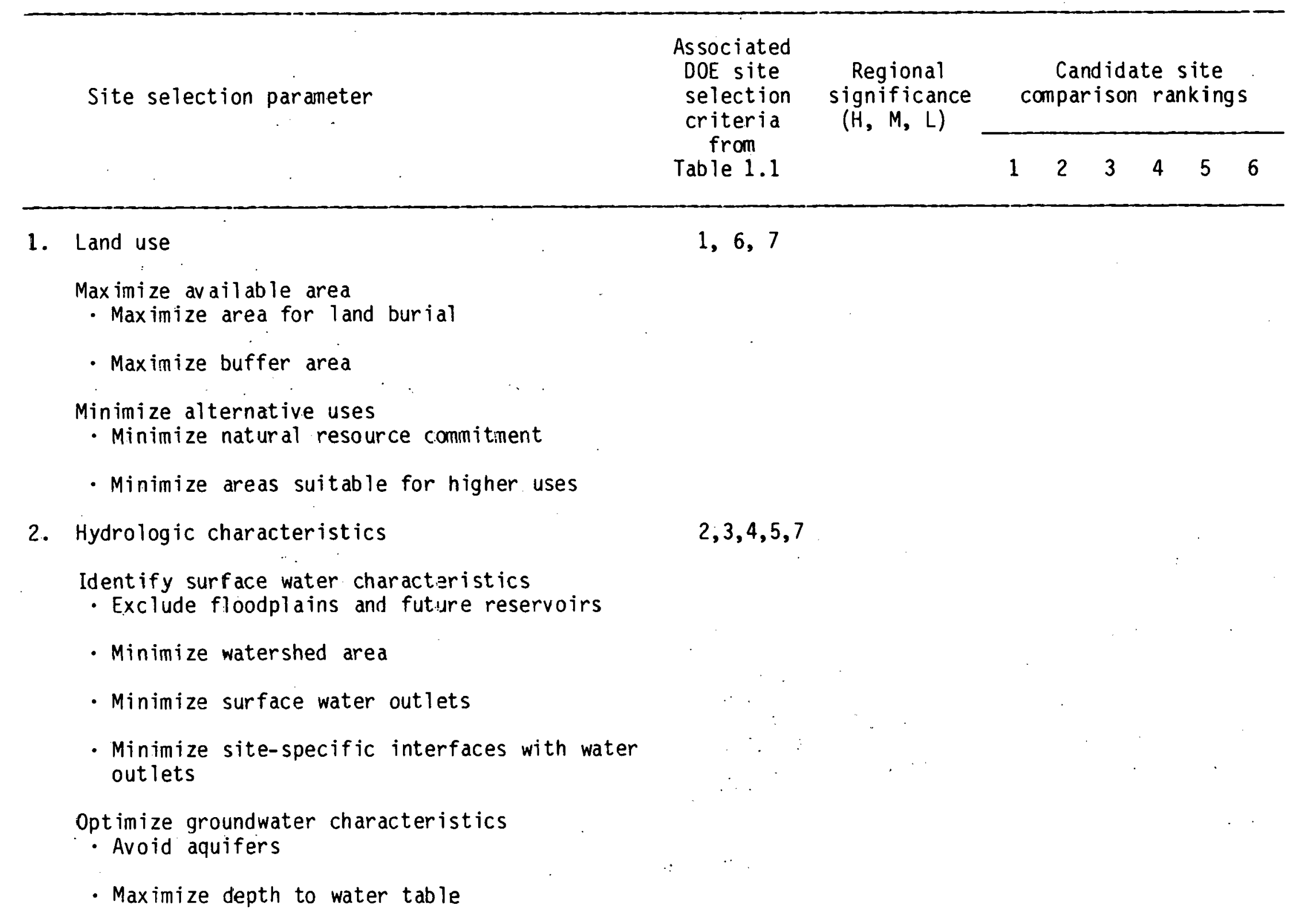


Table 2.1 (continued)

\begin{tabular}{|c|c|c|c|c|c|c|c|c|}
\hline \multirow[t]{2}{*}{ Site selection parameter } & \multirow{2}{*}{$\begin{array}{l}\text { Associated } \\
\text { DOE site } \\
\text { selection } \\
\text { criteria } \\
\text { from } \\
\text { Table } 1.1\end{array}$} & \multirow{2}{*}{$\begin{array}{c}\text { Regione. } \\
\text { significance } \\
(H, M, L)\end{array}$} & \multicolumn{6}{|c|}{$\begin{array}{l}\text { Candidate site } \\
\text { comparison rankings }\end{array}$} \\
\hline & & & 1 & 2 & $\mathbf{3}$ & 4 & & 6 \\
\hline
\end{tabular}

- Minimize grouníwater flow's

- Maximize dispersion

Optimize water quaity

- Optimize pH and buffer capacity for

- Optimize redox condition for waste

Maximize predictatility and nonitorability

3. Geologic characteristics

Avoid geologic hazards s:ch solution cavities, seismic activity, landslides

Minimize slope

Minimize geologic complexity

Avoid mineral rescurces

4. Soil characteristics

Optimize physical properties

- Minimize erosion

- Maximize soil thickness 
Table 2.1 (continued)




Table 2.2. An example worksheet for comparing candidate sites on the bas is of a single site selection parameter

\begin{tabular}{lccccccc}
\hline & \multicolumn{7}{c}{ Comparison sites } \\
\cline { 2 - 7 } Site & A & B & C & $D$ & E & $F$ \\
\hline A & XXXa & + & + & 0 & + & + \\
B & - & $X X X$ & - & - & 0 & - \\
C & - & + & $X X X$ & + & - & + \\
D & 0 & + & - & $X X X$ & + & + \\
E & - & 0 & + & + & $X X X$ & 0 \\
F & - & + & - & + & 0 & $x X X$ \\
\hline
\end{tabular}

$\operatorname{axxX}=$ same site; $+=$ better $; 0=$ same; - = worse .

developer rather than by the slight superiority established by the ranking exercise. The objective of the identification of the preferred site is not necessarily to identify the best site because the available information limits the capability of making such a determination. Instead, the preferred site should be the site which is best sulted to the needs of the developer and wich can satisfy the site selection criteria.

The results of the site screening process should be documented. The screening requirements, site selection parameters and their significance, comparative ranking of the slate of candidate sites, and judgments leading to the identification of the preferred site should be included.

\subsection{Site Characterization}

The site characterization stage evaluates in depth the suitability of the preferred site for low-level waste disposal based on conformance with the site selection criteria. If the site cannot meet the site selection criteria, then a return to the site screening stage is necessary to identify an alternative site. This process is sumarized in Fig. 2.5. 


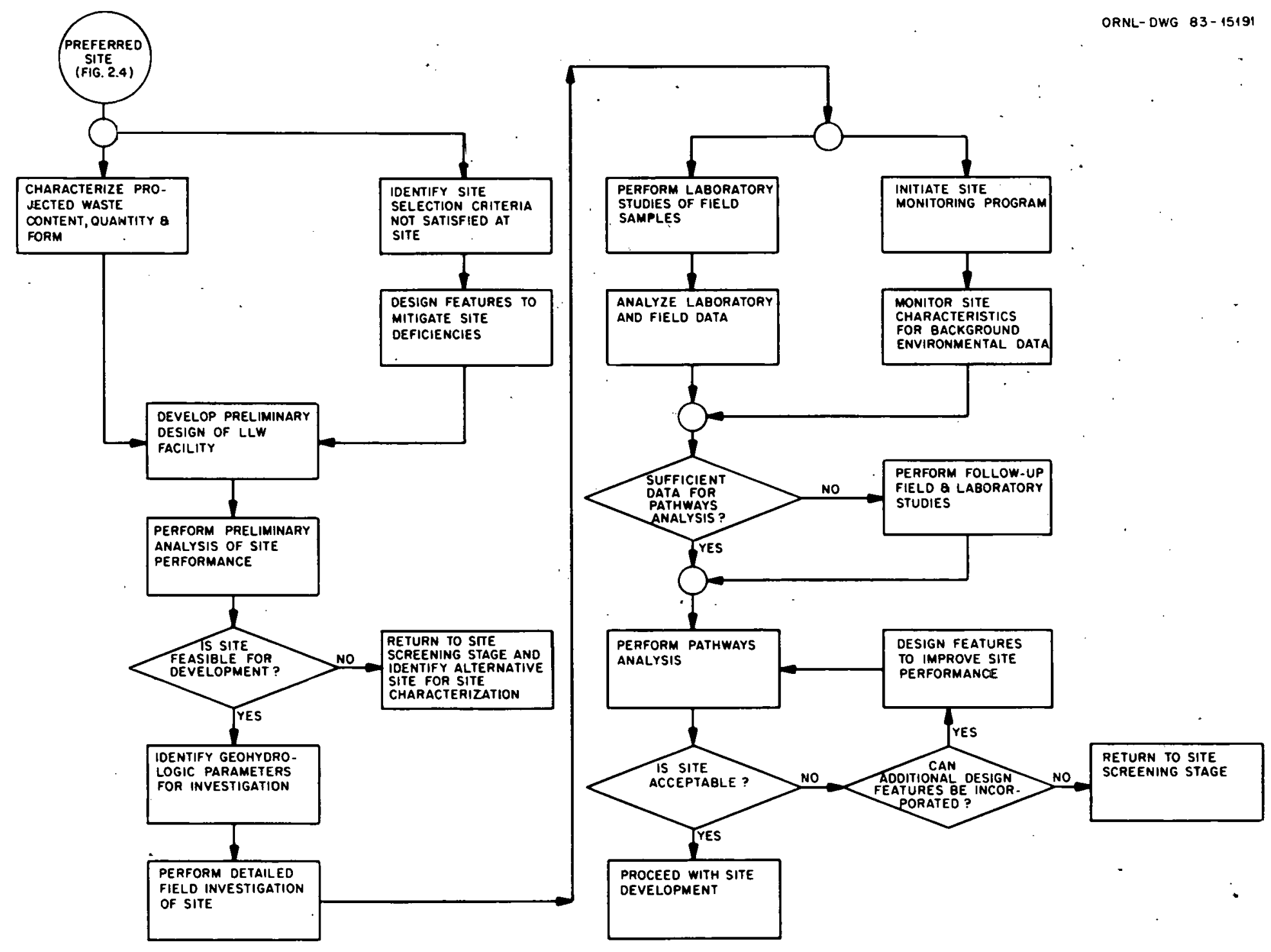

Fig. 2.5. Methodology for site characterization. 
The site characterization stage includes preliminary investigation of site feasibility, a comprehensive field study, a laboratory analys is of field samples, a site monitoring program, and a pathways analysis. The methods employed at this stage are considerably more costly and time consuming than site screening. Prudence, therefore, dictates that the activities most likely to discover critical deficiencies be performed first. Additionally, the site characterization activities should be coordinated with the data needs for site design so that any necessary engineered features can be identifled and ractored into thc craluation of site perfuriliale. Characterization provides the site-speçific dalia needed for verifying the compliance of the site with the site selection criteria and for establishing the requirements for site design and utilization.

\subsubsection{Site feasibility investigation}

The site feasibility investigation provides a preliminary concept of site utilization and performance and initiates the interaction of site design with the field investigation, laboratory studies, pathways analysis, and environmental monitoring activities. The site feasibility study includes a characterization of the radioactive waste, a preliminary design of site utilization, and a preliminary analys is of site performance. The site feasibility investigation can result in a field investigation that is more cost-effective, a pathways analysis that is more representative of facility operation and environmental data more useful for analysis and design.

Characterization of the radioactive waste content in terms of its physical and chemical form, quantity, and radionucilide concentrations is essential for defining the scope of the rield investigation, for perform= ing the pathways analysis, and for establishing lie design requtruments for site utilization. Characterizing the projected radioactive waste will aid in the evaluation of the site's capability to meet the disposal needs of waste generators in the regiun of interest. The characteristics of interest include the solubility of the radioactive isotopes contained in the waste, and the retardation factor of these isotopes in site soils with 
site hydrogeological conditions: The waste should be characterized as completely as possible to focus more sharply the scope of the remainder of the site characterization activities.

The preliminary design is intended to bound the scope of the field investigation and should encompass siting, operation, closure, and postclosure considerations. The preliminary design should seek to identify the necessary facilities, the proposed layout of projected trenches, the typical design of the trenches, and any proposed engineered design features for enhancing natural site performance. The preliminary design will aid in the identification of data needs to be incorporated into the field and laboratory investigations for the evaluation of site performance and for further design development.

The preliminary analys is of site performance is intended to identify the critical pathways of radionuclide transport. The potential pathways for migration of radionuclides from the site to the surrounding environment should be examined to estimate the potential exposure to the public and to identify apparent deficiencies in the natural site conditions. Any significant deficiencies detected at this level of analys is should become the focus of the field investigation and should be considered for mitigation by proposed engineered design features as part of the feasibility study. Site selection criteria not satisfied by the existing site conditions, based on the preliminary analys is of site performance, should be identified. Engineered design features that would improve site performance to the extent that the site selection criteria would be satisfied should be considered as part of the preliminary analysis. The scope of the detailed field investigation and pathways analys is should be expanded to evaluate any potential deficiencies detected during the preliminary analys is. Some sites may lack sufficient data for preliminary analysis. For these sites, a limited field investigation of the site may be appropriate. This investigation should be limited to providing data for performing a preliminary andiys is and for identifying the scope of the detailed field investigation. The data needs for providing the detailed design and the data necessary to evaluate the site's suitability for low-level waste disposal should be included in the subsequent field and laboratory investigations. 
The results of the site feasibility investigation should be documented to aid in the field and laboratory investigations and the pathways analysis. The site feasibility report should conclude if the site is feasible for further consideration for the disposal of low-level radioactive waste.

\subsubsection{Field investigation}

The field investigation of the preferred site provides the necessary site-specifir data for the evaluation of site performance and for further site developilent. The field investigation is comprehensive in scope and requires the utilization of technical specialists and specialized equipment. Geological and hydrological investigations of site conditions are the primary focus of the fleld pruyrain. Additional areas of investigation may be significant depending on site-specific conditions and on the results of the site feasibility investigation. A detailed discussion of the important factors to be considered for incorporation into the field investigation is included in the Shallow Land Burial Handbook. 1 The field investigation should also include the initiation of the environmental monitoring proyram (Sect. 2.2.4) and the retrieval of the necessary samples for laboratory investigation (Sect. 2.2.3). Because the field investigation is intended to provide site-specific data for several needs, the program should be carefully considered and planned prior to implementation to minimize costs. The results should be documented along with the results of the laboratory investigation for the pathways analysis and with the detailed facllity design.

\subsubsection{Laboraluiy investigation}

Laboratory analysis of field samples is necessary to interpret field data, confirm field observations, and assist in defining any additional field activities. A detailed discussion of the laboratory analyses appropriate for the site characterization stage is included in the Shallow Land Burial Handbook. 1 Laboratory analysis should be included in the 
site characterization stage to the extent necessary to establish a complete data set for site evaluation and design.

\subsubsection{Monitoring program}

The monitoring program is initiated during site characterization to establish background environmental data and to determine seasonal variations in the environmental data. The hydrological aspects of the monitoring program are especially important for establishing the data base for pathways analys is and site design. A discussion of the monitoring program is included in the Shallow Land Burial Handbook ${ }^{1}$ and the Generic Handbook on Environmental Monitoring for Low-Level Waste Disposal Sites. ${ }^{2}$

\subsubsection{Pathways analys is}

The pathways analysis determines if the preferred site can satisfy the site selection criteria, performance objectives, and technical requirements (Tables 1.1 and 1.2 ). The potential pathways for consideration in the pathways analys is include groundwater transport, intrusion, surface water transport, atmospheric transport, and consumption of food grown at or around the site. The pathways are summarized in Fig. 2.6.

The pathways analysis considers conservative scenarios of site development for investigation of potential releases of radioactivity to the public. Credit for engineered design features proposed for the site is incorporated into the analys is scenarios as are the site-specific data collected during the field and laboratory investigations. The results of the pathways analysis are used to determine the size of the huffer zone and to establish design requirements for site suitability. The pathways analys is may determine limitations on waste form and quantity, establish the need for additional monitoring activities during operation and closure, or define additional design requirements for site acceptability. 
CIRNL-DWG $82-14845$

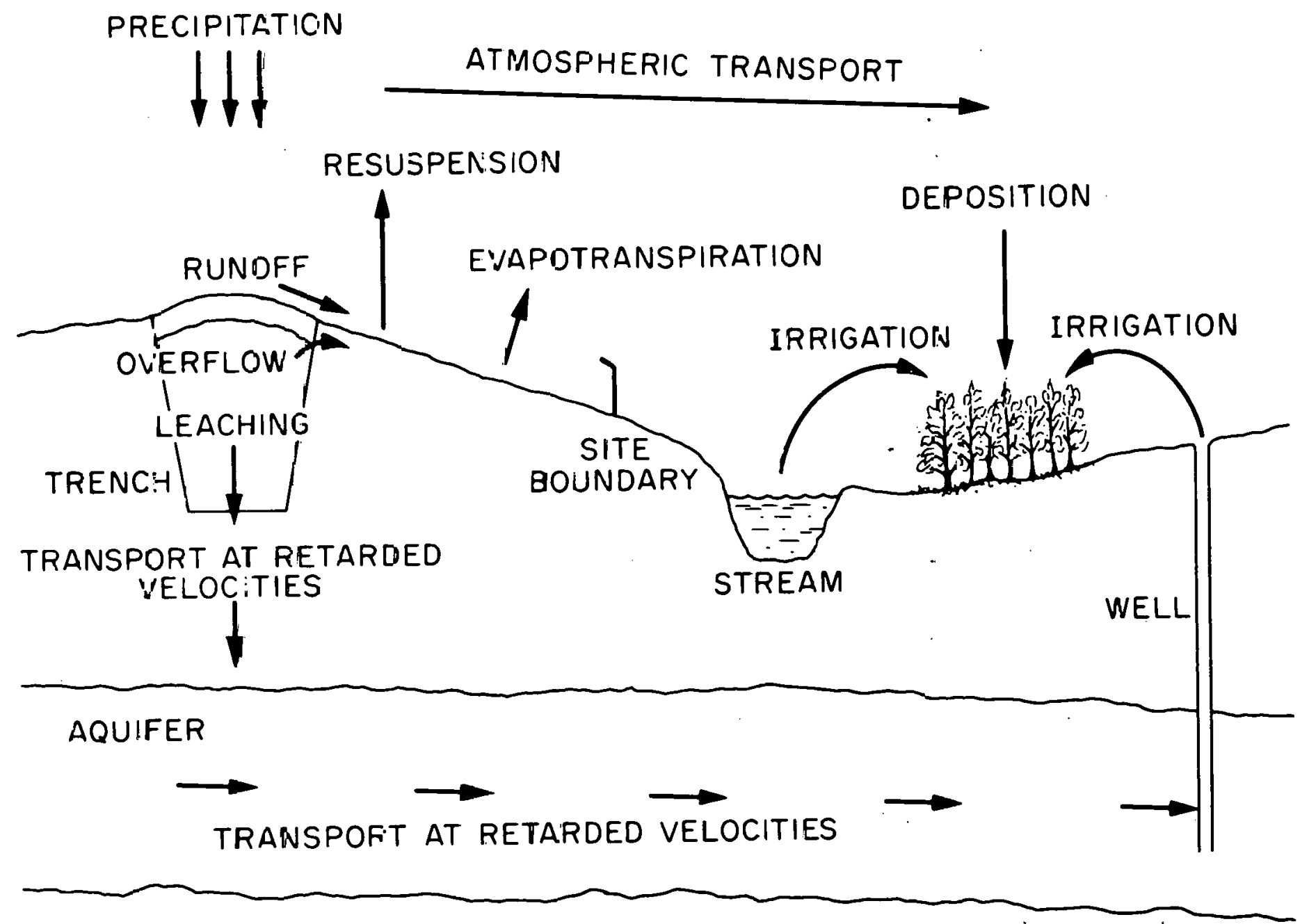

Fig. 2.6. Environmental pathways for release of radioactivity frown low-level waste disposal facilities. 
If the pathways analysis results indicate that the site is unacceptable for low-level waste disposal, then additional designed features, limitations on site utilization, or alternative sites need to be considered. If the pathways analys is results indicate that the site is acceptable, the site selection process is completed and site development proceeds to detailed design. The pathways analys is should be documented for future use in facility design, operation, monitoring, and closure. 
REFERENCES -- SECTION 2

1. Department of Energy, Low-Level Waste Management Program, Shal low Land Burial Handbook, ORNL/NFW-82/73, 1982.

2. Department of Energy, Low-Level Waste Management Program, Generic Handbook on Environmental Monitoring for Low-Level Waste Disposal Sites, ANL-038-02-82, 1982. 
The DOE site selection criteria were applied to the DOE Oak Ridge Reservation using the methodology in Sect. 2 to provide a test case of the utility of the methodology and to compare the results to other siting studies of the area. For this application, DOE was the developer and the region of interest was defined as the reservation. The limited size of the 0ak Ridge Reservation as a region of interest narrows the geologic and hydrologic environments from which a site can be selected. The effect of this restricted region of interest is evident in the application of the criteria. The methodology for applying the criteria is applied only through the site screening stage. The site characterization stage is beyond the scope of this analysis but would be necessary before completion of the site selection process.

\subsection{Candidate Area Identification}

The candidate area screening requirements and the associated DOE site selection criteria for application to the Oak Ridge Reservation are presented in Table 3.1. Local and regional data of the geologic formations that outcrop on the Oak Ridge Reservation were used for the identification of areas with adequate soil thickness above bedrock. 1 Terrains underlain by units of the Conasauga and Knox Groups are more likely to have soil thicknessess exceeding $10 \mathrm{~m}(30 \mathrm{ft})$ than are terrains underlain by the Rome Formation and the Chickamauga Group. The 100-year floodplain, presence of wetlands, and land previously used for the burial of waste were identified from the data contained in the 0ak Ridge Reservation Land-Use Plan. ${ }^{2}$ Areas with potentially adequate unsaturated zone thicknesses were estimated by excluding all areas, with less than $7 \mathrm{~m}(20 \mathrm{ft})$ of elevation above the surface water budies indicated on the topographic map of the Oak Ridge Reservation. The candidate areas rematning were examined to ensure that an adequate number of possible sites were present with in the candidate areas to conduct a valid site comparison incorporating regional variability. The candidate areas and the potential sites within 
Table 3:1. Candidate area screening requirements for the Oak Ridge Reservation



aNumbers indicate the criteria presented in Table 1.1.

each candidate ared are summarized in Table 3. $\ddot{2}$. The candidatc areas identitien are shown in Fig. 3.1 .

\subsection{Candidate Site Identification}

The candidate site screening requirements for application to the candidate areas are presented in Table 3.3. The requirements include both exclusionary and destrable features for a site. Tracts of land with slopes greater than $25 \%$ were identified by a topographic slope analysis using a 1:24000 map. The sccurity hnundary around existing plants, public roads, and the reservation boundary was identified. The presence of karst topography is not accurately noted on the available map of the Oak Ridge Reservation because karst features are too subtle to be identified on maps with such a large scale. Karst features, which are comonly observed as closed topographic depressions that do not collect surface runoff, are 
Table 3.2. Candidate areas and potential sites within candidate areas

Candidate area Potential site

Bear Creek Valley

Exxon

Bear Creek Valley

Chestnut Ridge

West Chestnut Ridge

Central Chestnut Ridge West section Central section East section

East Chestnut Ridge

Blackoak Ridge

West Blackoak Ridge

East Blackoak Ridge

Copper Ridge

\author{
Melton Valley \\ Copper Ridge \\ West section \\ Central section \\ East section
}

Freels Bend

Freels Bend

Valley section

Peninsula section

associated with subsurface cavities or drainage in the bedrock and are prevalant in the Knox Group areas. The presence of karst topography and current residential development in the candidale areas were established by field inspection. The inspection of the candidate areas provided input for site screening and ranking. 


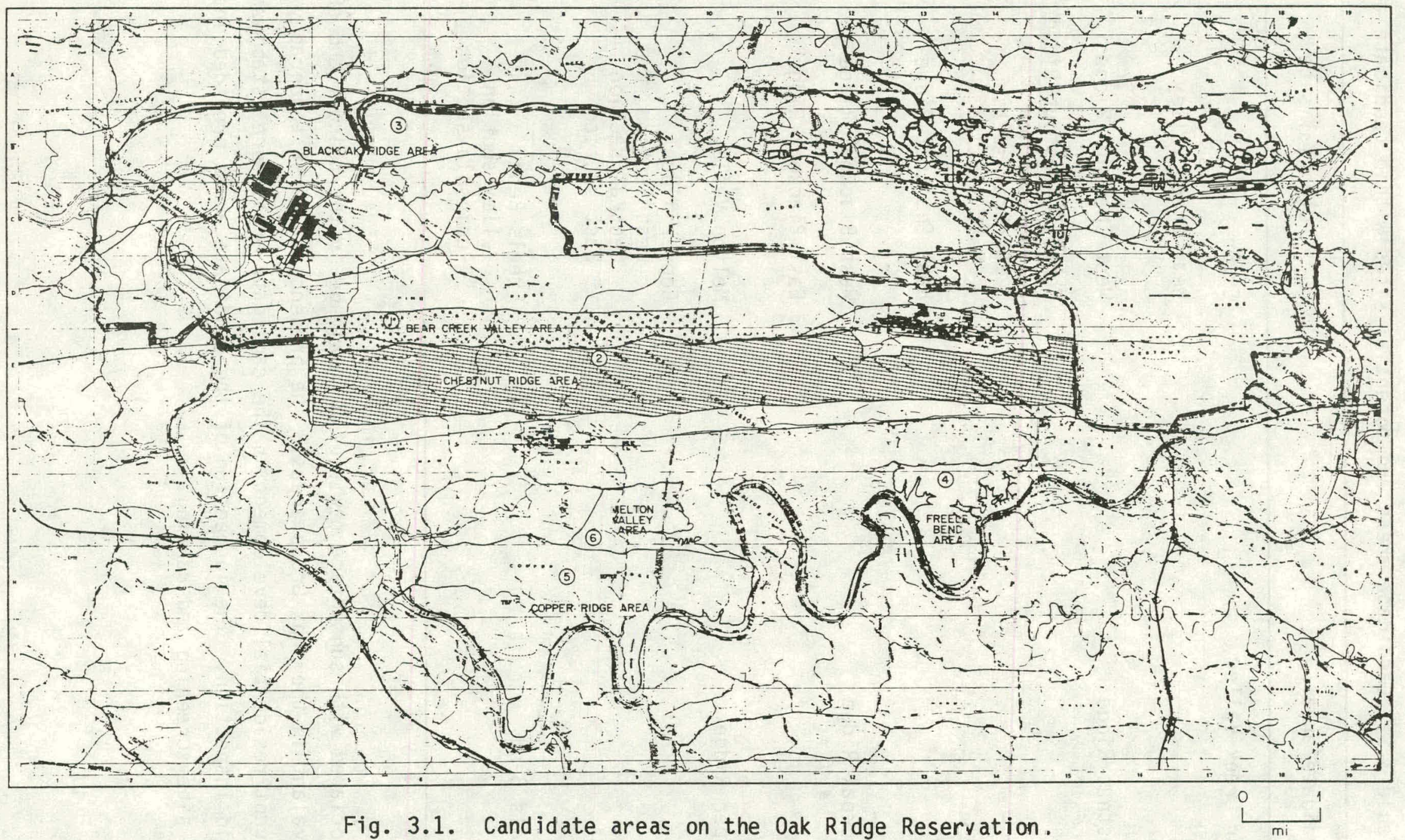

Fig. 3.1. Candidate areas on the Oak Ridge Reservation. 
Table 3.3. Candidate site screening requirements for the Oak Ridge Reservation

Requirements

Related DOE

site selection

criteriaa

Exclusionary requirements:

1. Exclude areas with evidence of karst topography

2. Exclude areas with slope greater than $25 \%$

6,3

3. Exclude areas that do not fall within a security boundary defined as

$250 \mathrm{~m}$ from existing plants

$250 \mathrm{~m}$ from public roads

$250 \mathrm{~m}$ from reservation boundary

4. Exclude areas adjacent to residential development

6

Desirable features:

1. Available area greater than 80 ha (200 acres) 1,5

2. Slope less than $10 \% \quad 6,3$

3. Easy access to site by road 6

4. Site in close proximity to waste generators 6

5. Utilities available for site development 6

aNumbers ind icate the criteria presented in Table 1.1.

As a consequence of the field inspection, the Freels Bend area and the Copper Ridge area were excluded from further consideration because of the abundance of karst in areas with slopes potentially suitable for waste disposal. The Blackoak Ridge area was excluded from further consideration because the tracts of 1 and satisfying the site screening requirements were close to the boundary of the Oak Ridge Reservation, and residential development was adjacent to the reservation boundary in this area. Karst development was present in all of the attractive tracts of land in the 
Blackoak Ridge area, further detracting from its viability for low-level waste disposal. The Melton Valley area was excluded from further consideration because insufficient area is available for disposal that is outside of the tract being investigated currently for low-level waste disposal at Oak Ridge National Laboratory.

Candidate sites within the remaining candidate areas were identified. The slate of candidate sites remaining for analysis and the associated geologic unit are presented in Table 3.4. The location of each site is shown in Fig. 3.2. The slate of candidate sites includes both geologic units putentially sultable for waste disposal and the variability of terrestrial and hydrologic environmenls within the reservation.

\subsection{Preferred Site Ident ification}

Identification of a preferred site involves data collection, site selection criteria evaluation, and candidate site ranking. Data were collected for the candidate sites from a literature survey and site $v$ isit and were reviewed in light of the requirements for the ranking of the candidate sites. Next the parameters of interest from the DOE site selection criteria were developed. This exercise had been complcted previously as part of the tables prepared for the site selection methodology (Table 2.1, Sect.2). These parameters were reviewed and found to be appropriatc for application to the Oak Ridge Reservation.

Finally, the ranking of the candidate sites was performed. The ranking of candidate sites requires that the significance of the site selection parameters be identified for the region of interest. The significance factors identifed for the Oak Ridge Reservation were

- Hydrology high

- Geology

- high

- Soils

- medium

- Land Use

- medium

- Socioeconomics

- low

- Ecology and Meteorology - low 
Table 3.4. Candidate sites within the Oak Ridge Reservation

\begin{tabular}{lc}
\hline Candidate site & Geologic group \\
\hline Exxon & Conasauga \\
Bear Creek Valley & Conasauga \\
West Chestnut Ridge & Knox \\
$\begin{array}{l}\text { Central Chestnut Ridge } \\
\text { West section } \\
\text { Central section } \\
\text { East section }\end{array}$ & Knox \\
East Chestnut Ridge & Knox
\end{tabular}

Hydrology and geology were identified as having high significance because of their obvious role in the stability and transport of contamination after disposal. Soils was identified as having medium significance because soil characteristics can significantly contribute to the performance of a site and their presence is essential to the disposal of waste by shallow land burial. Land use was identified as having medium significance because of the limited availability of land suitable for disposal and the many competing interests for use of the available 1 and. 2 Socioeconomics was identified as having low significance because, exclusive of the area near the reservation boundary, the 1 and on the reservation is strictly within the cuntrol and administration of DOE. Ecology and meteorology were identified as having low significance because of the limited variability within the reservation.

The available data for each of these parameters (Table 2.2) were reviewed for each site, and a comparison of candidate sites was perfurmed. Sites were compared as better, the same, or worse with respect to each other. These comparisons are included in Tables 3.5 to 3.10. The three sections of the Central Chestnut Ridge site were treated separately with the understanding that they could be recombined to form a consolidated site later in the analysis. 
ORNL-DWG 83-15192

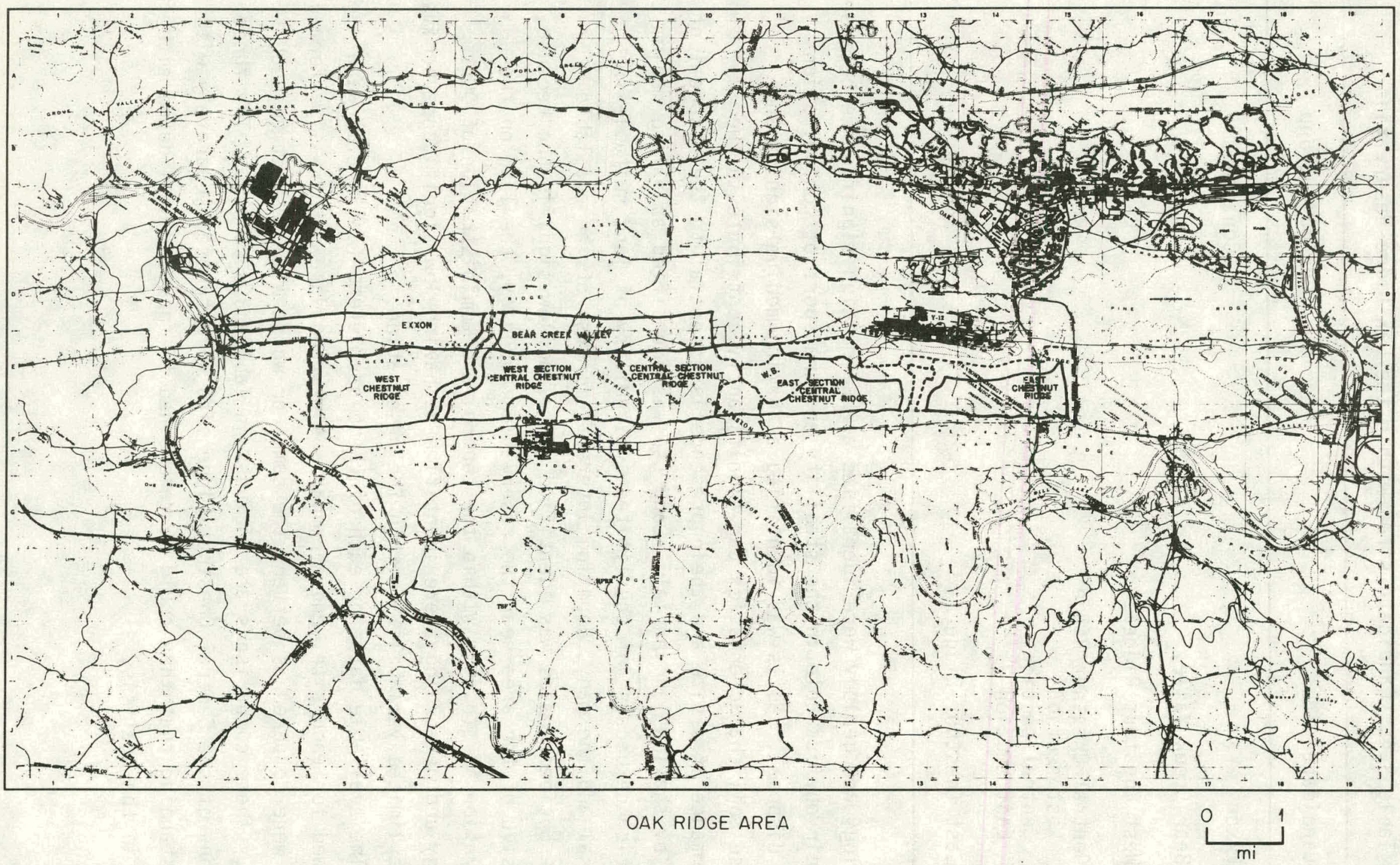

Fig. 3.2. Candidate sites on the Oak Ridge Reseriation. 
Table 3.5 presents the comparison of the sites with respect to their hydrologic characteristics. These include surface water, groundwater, water quality, and hydrogeologic predictability. The Conasauga Group sites were comparatively worse than the Knox Group sites because of comparatively shallow groundwater. Surface water outlets and site interfaces with surface water are more common in the Conasauga Group sites than in the Knox Group sites. The Conasauga and Knox Groups are both difficult to model. Flow in the Conasauga Group is fracture dominated, and flow in the knox Group is dominated by solution cavities. An improved understanding of the depth properties and extent of the soils at the Knox Group sites may result in sufficient data to predict'hydrologic transport in the unsaturated zone. "The West Section of Central Chestnut Ridge and East Chestnut Ridge were noted to be the most attractive because of their comparative lack of springs and surface water. The other Knox Group sites were considered less attractive because of the abundance of springs and surface water outlets. East Chestnut Ridge was considered the most attractive site because of the ease in monitoring site runoff and present land use. The site is presently pasture whose hydrological behavior is similar to that expected after facility development.

Table 3.6 presents the comparison of the sites with respect to their geologic characteristics. These characteristics include geologic hazards, slope, geologic complexity, and mineral resources (Table 2.1). The Conasauga sites were comparatively superior to the Knox Group sites because of gentler slopes and the absence of geologic hazards. Both the Knox and Conasauga Groups are geologically complex; however, the Conasauga Group is comparatively homogeneous. The Knox Group has an irregular bedrock surface made more complex by the presence of solution cavities. The associated karst development detracts from the geologic suitability of the Knox Group sites. The Central Section of Central Chestnut Ridge was the most attractive Knox Group site because of the comparatively favorable topography in the area with the deepest soil. West Chestnut Ridge was nearly as attractive but had smaller tracts of acreage with gentle slopes. Karst features were observed in several stratigraphically controlled zones on both sites. 
Table 3.5. Comparison of sites - hydrology Significance: High

\begin{tabular}{|c|c|c|c|c|c|c|c|c|}
\hline \multirow{3}{*}{\multicolumn{2}{|c|}{ Site }} & \multicolumn{7}{|c|}{ Comparison sites } \\
\hline & & \multirow[b]{2}{*}{ Exxon } & \multirow[b]{2}{*}{$\begin{array}{l}\text { Bear } \\
\text { Creek } \\
\text { Valley }\end{array}$} & \multirow[b]{2}{*}{$\begin{array}{l}\text { West } \\
\text { Chestnut } \\
\text { Ridge }\end{array}$} & \multicolumn{2}{|c|}{ Central Chestnut } & \multirow{2}{*}{$\begin{array}{l}\text { Ridge } \\
\text { East } \\
\text { saction }\end{array}$} & \multirow[b]{2}{*}{$\begin{array}{l}\text { East } \\
\text { Chestnut } \\
\text { Ridge }\end{array}$} \\
\hline & & & & & $\begin{array}{l}\text { West } \\
\text { section }\end{array}$ & $\begin{array}{l}\text { Central } \\
\text { section }\end{array}$ & & \\
\hline Exxor & & 1111 & 0 & - & - & - & - & \\
\hline $\begin{array}{l}\text { Bear } \\
\text { Valle }\end{array}$ & $\begin{array}{l}\text { Creek } \\
\text { ey }\end{array}$ & 0 & 11 & - & - & - & - & - \\
\hline $\begin{array}{l}\text { West } \\
\text { Ridge }\end{array}$ & Chestnut & + & + & 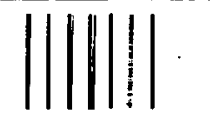 & - & - & 0 & - \\
\hline \multirow{3}{*}{ 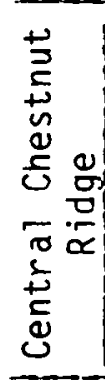 } & $\left\{\begin{array}{l}\text { West } \\
\text { section }\end{array}\right.$ & + & + & + & 11111 & + & + & - \\
\hline & $\begin{array}{l}\text { Central } \\
\text { section }\end{array}$ & + & + & + & - & $11 \| 1$ & + & - \\
\hline & $\begin{array}{l}\text { East } \\
\text { section }\end{array}$ & + & + & D & - & - & $\|$ & - \\
\hline $\begin{array}{l}\text { East } \\
\text { Ridg! }\end{array}$ & Chestndt & + & + & + & + & + & + & \\
\hline
\end{tabular}


Table 3.6. Comparison of sites - geology Significance: High

\begin{tabular}{|c|c|c|c|c|c|c|c|c|}
\hline \multirow{3}{*}{\multicolumn{2}{|c|}{ Site }} & \multicolumn{7}{|c|}{ Comparison sites } \\
\hline & & \multirow[b]{2}{*}{ Exxon } & \multirow[b]{2}{*}{$\begin{array}{l}\text { Bear } \\
\text { Creek } \\
\text { Valley }\end{array}$} & \multirow[b]{2}{*}{$\begin{array}{l}\text { West } \\
\text { Chestnut } \\
\text { Ridge }\end{array}$} & \multicolumn{3}{|c|}{ Central Chestnut Ridge } & \multirow[b]{2}{*}{$\begin{array}{l}\text { East } \\
\text { Chestnut } \\
\text { Ridge }\end{array}$} \\
\hline & & & & & $\begin{array}{l}\text { West } \\
\text { section }\end{array}$ & $\begin{array}{l}\text { Central } \\
\text { section }\end{array}$ & $\begin{array}{l}\text { East } \\
\text { section }\end{array}$ & \\
\hline \multicolumn{2}{|c|}{ Exxon } & \|\|$\|$ & 0 & + & + & + & + & + \\
\hline \multicolumn{2}{|c|}{$\begin{array}{l}\text { Bear Creek } \\
\text { Valley }\end{array}$} & 0 & 11111 & + & + & + & + & + \\
\hline \multicolumn{2}{|c|}{$\begin{array}{l}\text { West Chestnut } \\
\text { Ridge }\end{array}$} & - & - & 1111111 & + & 0 & 0 & + \\
\hline \multirow{3}{*}{  } & $\begin{array}{l}\text { West } \\
\text { section }\end{array}$ & - & - & - & \|\|$\|$ & - & 0 & - \\
\hline & $\begin{array}{l}\text { Central } \\
\text { section }\end{array}$ & - & - & 0 & + & & + & + \\
\hline & $\begin{array}{l}\text { East } \\
\text { section }\end{array}$ & - & - & 0 & 0 & - & & 0 \\
\hline \multicolumn{2}{|c|}{$\begin{array}{l}\text { East Chestnut } \\
\text { Ridge }\end{array}$} & - & - & - & + & - & 0 & \\
\hline
\end{tabular}

a \|\|\|\|$=$ same site; $t=$ better than, such as large tracts of land with attractive slope (see Table 2.1); - = worse than, such as the presence of extensive karst development (see Table 2.1);0 = no difference. 
Table 3.7 presents the comparison of soil characteristics including physical and chemical features of the soil. The available data for the Knox Group sites and Conasauga Group sites were more generic than site specific. The Conasauga Group sites were considered to be comparatively less attractive because of the relatively thin unsaturated layer at these sites as compared to the Knox Group sites. The Conasauga Group solls have clay minerals with high sorptive capacities and moderate ion-exchange capacities. The Knox Group soils are generally lower in sorptive capacity and ion-exchange capacity. The superior chemical characteristirs of the Conasauga soils are offset. by their limited thickness.

Table 3.8 presents the comparison of land-use chardcleristics including the available area and alternative land uses. The Conasauga Group sites were considered to be better because the available acreage was in larger sized parcels and in more concentrated groups. The Bear Creek Valley site was considered the best since it had more useable acreage than the Exxon site. The East Section of the Central Chestnut Ridge site was considered to be the least acceptable because of the present use of the section for the $Y-12$ landfil1, United Nuclear Corporation (UNC) waste disposal, and the Walker Branch Watershed Laboratory. These present uses exclude portions of the East section and detract from the viability of the East section for waste disposal.

Table 3.9 presents the comparison of the sites with respect to the socioeconomic characteristics including potential impacts to the local population, site access, and the proximity of utilities to the site. The Conasauga sites are the most attractive because of their ease of access and the availability of utilities. Potential impacts to population were considered to be similar for all of the sites since the sites are distant from the reservation boundary.

Table 3.10 presents the comparison of the sites with respect to ecological and meteorological characteristics. The meteorological characteristics are similar for all the sites. Ecological characteristics vary with the presence of habitats important to environmental research either proposed or being performed on the reservation. 
Table 3.7. Comparison of sites - soil Significance: Medium



a \|\|\|\|$=$ same site; $+=$ better than, such as thicker soils

(see Table 2.1); - = worse than, such as thin erosive soils (see Table 2.1); 0 = no difference. 
Table 3.8. Comparison of sites - land use

Significance: Medium

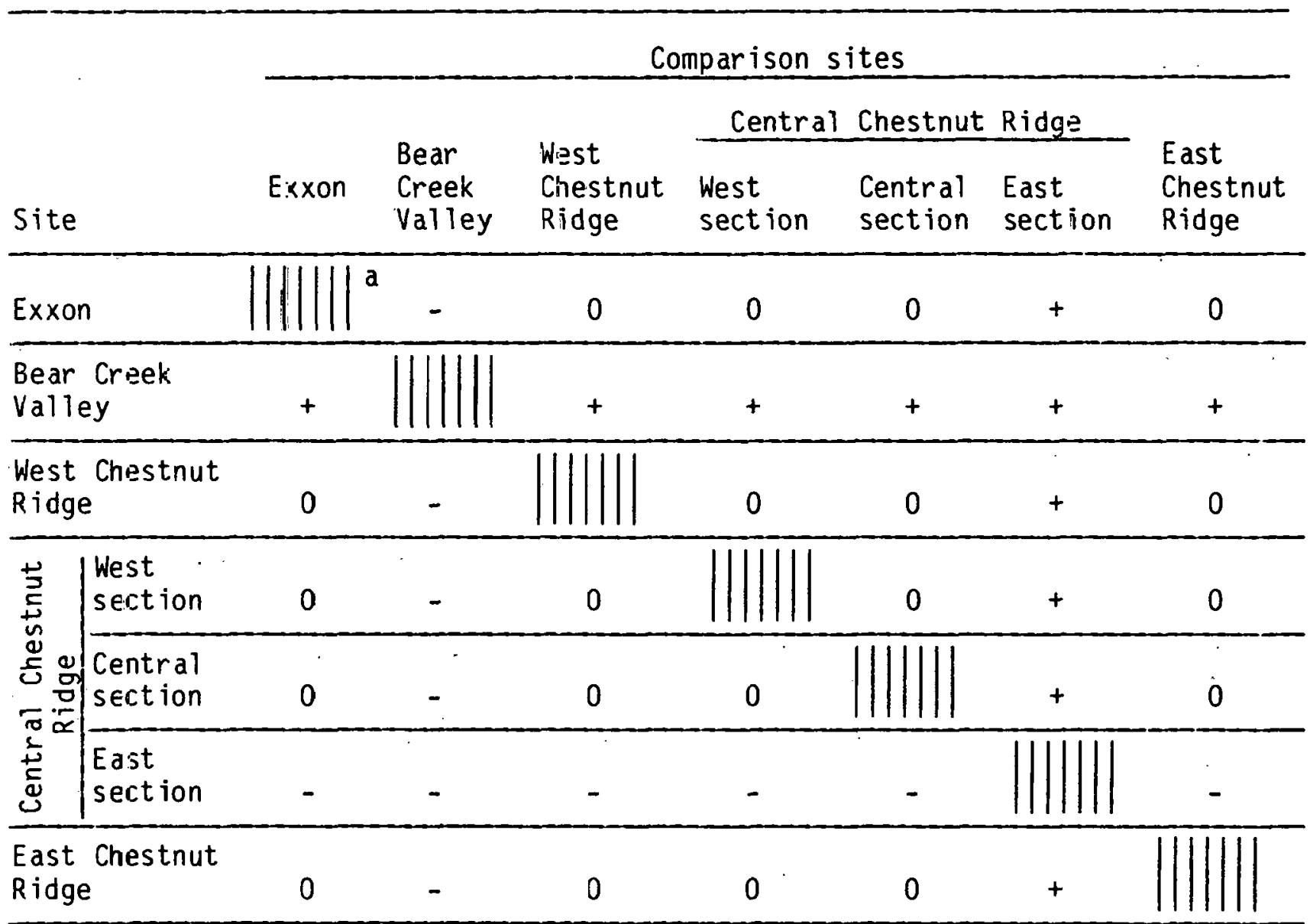

a \|\|\|\|$=$ same site; $+=$ better than, such as large tracts of attractive 1 and in a concentrated area (see Table 2.1); - = worse than, such as 1 and attractive for industrial development (see Table 2.1);0 = no difference. 
Table 3.9. Comparison of sites - socioeconomics Significance: Low

\begin{tabular}{|c|c|c|c|c|c|c|c|c|c|}
\hline \multirow[b]{3}{*}{ Site } & \multirow[t]{3}{*}{. } & \multicolumn{7}{|c|}{ Comparison sites } & \multirow[b]{3}{*}{$\begin{array}{l}\text { East } \\
\text { Chestnut } \\
\text { Ridge }\end{array}$} \\
\hline & & \multirow[b]{2}{*}{ Exxon } & \multirow{2}{*}{\multicolumn{2}{|c|}{$\begin{array}{l}\text { Bear } \\
\text { Creek } \\
\text { Valley }\end{array}$}} & \multirow[b]{2}{*}{$\begin{array}{l}\text { West } \\
\text { Chestnut } \\
\text { Ridge }\end{array}$} & \multicolumn{3}{|c|}{ Central Chestnut Ridge } & \\
\hline & & & & & & $\begin{array}{l}\text { West } \\
\text { section }\end{array}$ & $\begin{array}{l}\text { Central } \\
\text { section }\end{array}$ & $\begin{array}{l}\text { East } \\
\text { section }\end{array}$ & \\
\hline \multicolumn{2}{|c|}{ Exxon } & 11 & 0 & & + & + & + & + & + \\
\hline \multicolumn{2}{|c|}{$\begin{array}{l}\text { Bear Creek } \\
\text { Valley. }\end{array}$} & 0 & & & + & + & + & + & + \\
\hline \multicolumn{2}{|c|}{$\begin{array}{l}\text { West Chestnut } \\
\text { Ridge }\end{array}$} & - & $-i$ & & 11111 & 0 & - & $-'$ & 0 \\
\hline \multirow{3}{*}{ 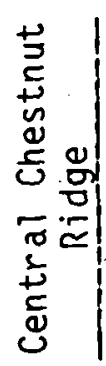 } & $\begin{array}{l}\text { West } \\
\text { sect ion }\end{array}$ & - & 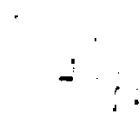 & & 0 & & - & - & 0 \\
\hline & $\begin{array}{l}\text { Central } \\
\text { section }\end{array}$ & - & - & & + & + & & 0 & + \\
\hline & $\begin{array}{l}\text { East } \\
\text { sect ion }\end{array}$ & - & - & & $\dot{t}$ & + & 0 & 111 & 0 \\
\hline \multicolumn{2}{|c|}{$\begin{array}{l}\text { East Chestnut } \\
\text { Ridge }\end{array}$} & - & - & & 0 & 0 & - & 0 & \|\|$\|$ \\
\hline
\end{tabular}

a \|\|\|\|$=$ same site; $+=$ better than, such as easy site access

(see Table 2.1); -"= worse than, such as distant from available utilities

( see Table 2.1 ); 0 = no difference. . 
Table 3.10. Comparison of sites - ecological and meteorological jignificance: Low

\begin{tabular}{|c|c|c|c|c|c|c|c|c|}
\hline \multirow{3}{*}{\multicolumn{2}{|c|}{ Site }} & \multicolumn{7}{|c|}{ Comparison sites } \\
\hline & & \multirow[b]{2}{*}{ Exxon } & \multirow[b]{2}{*}{$\begin{array}{l}\text { Bear } \\
\text { Creek } \\
\text { Valley }\end{array}$} & \multirow[b]{2}{*}{$\begin{array}{l}\text { West } \\
\text { Chestnut } \\
\text { Ridge }\end{array}$} & \multicolumn{3}{|c|}{ Central Chestnut Ridge } & \multirow[b]{2}{*}{$\begin{array}{l}\text { East } \\
\text { Chestnut } \\
\text { Ridge }\end{array}$} \\
\hline & & & & & $\begin{array}{l}\text { West } \\
\text { section }\end{array}$ & $\begin{array}{l}\text { Central } \\
\text { section }\end{array}$ & $\begin{array}{l}\text { East } \\
\text { section }\end{array}$ & \\
\hline \multicolumn{2}{|c|}{ Exxon } & 1\|\|$\|$ & + & + & 0 & + & + & 0 \\
\hline \multicolumn{2}{|c|}{$\begin{array}{l}\text { Bear Creek } \\
\text { Valley }\end{array}$} & - & & 0 & - & 0 & 0 & - \\
\hline \multicolumn{2}{|c|}{$\begin{array}{l}\text { West Chestnut } \\
\text { Ridge }\end{array}$} & - & 0 & & - & 0 & 0 & - \\
\hline \multirow{3}{*}{ 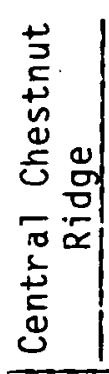 } & $\begin{array}{l}\text { West } \\
\text { section }\end{array}$ & 0 & + & + & 11 & + & + & 0 \\
\hline & $\left\{\begin{array}{l}\text { Central } \\
\text { section }\end{array}\right.$ & - & 0 & 0 & - & 111 & 0 & - \\
\hline & $\begin{array}{l}\text { East } \\
\text { section }\end{array}$ & - & 0 & 0 & - & 0 & & - \\
\hline \multicolumn{2}{|c|}{$\begin{array}{l}\text { East Cr:estnut } \\
\text { Ridge }\end{array}$} & 0 & + & + & 0 & + & + & \\
\hline
\end{tabular}


The results of the comparative ranking were assembled and are presented in Table 3.11. Sites that were comparatively better than the other sites were ranked highest with equivalent rankings given to similar sites. Several sites had equivalent rankings for several parameters. This result was expected because of the many similar features of the candidate sites. The rankings of the sites were dramatically different for hydrology and geology, the two parameters of high concern.

The parametric rankings were interpreted to provide an overall ranking of the candidate sites. The results are not definitive for most sites. The ranking of the Conasauga Group sites over the Knox Group sites is dependent on the relative importance assigned to hydrologic and geologic characteristics. Debate surrounding this important point is longstanding and ongoing. Naturally, the ranking procedure cannot be expected to resolve such a technical issue; however, the viability of the procedure is enhanced because the basis for debate is clearly illustrated.

For the two sites in the Conasauga Group, the Bear Creek Valley site was ranked higher based on land use considerations. The sites are equivalent for all parameters except for land use and ecology/meteorology.: The Exxon site was previously proposed as an industrial site and may be attractive as an industrial site in the future. The use of the Exxon site for low-level waste disposal would el iminate this alternative. Additionally, the larger available acreage potentially suitable for waste disposal in the Bear Creek Valley site enhances the possibility of finding sufficient acreage for disposal that can satisfy the site selection criteria. The Exxon site was ranked superior to the Bear Creek Valley site with respect to ecology/meteorology because the latter site has been identified for the study of the recovery of an impacted habitat from acid and nitrate pollution. ${ }^{2}$ Overall, the Conasauga Group sites are superior to the Knox Group sites with respect to geologic characteristics and socioeconom ic characteristics. The Knox Group sites are superior to the Conasauga Group sites with respect to hydrologic and soil characteristics.

The Knox Group sites were roughly equivalent to each other except for the East section of Central Chestnut Ridge. The East section was very unattractive from the standpoint of land-use characteristics. East 
Table 3.13. Ranking of sites for site selection paraneters




Chestnut Ridge had the most attractive hydrologic characteristics with the West section of Central Chestnut Ridge having comparatively advantageous hydrologic features. The slight superiority of the Central section of Central Chestnut Ridge with respect to geology and socioeconomics resulted in it being ranked the highest of the Knox Group sites. However, East Chestnut Ridge could be considered the most superior Knox site if hydrologic characteristics are considered to be of greater importance than geologic characteristics for Knox Group sites.

The overall summary of results of the ranking exercise is shown in Table 3.12. Further development of data would be necessary to establish which of the top four knox Group sites is more advantageous. The results of this analysis suggest that the amount of data necessary to establish. the relative superiority of the top Knox or Conasauga Group site is prodigious because of the difficulty in defining the relative significance of hydrologic and geologic characteristics. The results of this study suggest that both the knox and Conasauga Group sites have deficiencies that detract from their suitability for low-level waste disposal and that must be addressed in the design of a low-level waste disposal facility.

The results of this application of the site selection criteria do not identify a clearly environmentally superior site. In such cases, the preferred site is best determined by the other interests rather than by attempting to force a definitive conclusion. Other interests that would be important in identification of the preferred site that are not included in this study include prior operating experience, costs of site development, and detailed facility needs. To date, the bulk of existing experience with low-level waste disposal on the Oak Ridge Reservation has occurred in the Conasauga Group. Limited experience exists for the Chickamauga Group at ORNL SWSA\#3, and that experience was not encouraging. ORNL low-level waste disposal operations subsequently were relocated in the Conasauga Group. Experience with the Knox Group has been limited to one area on Blackoak Ridge used for low-level waste disposal from ORGDP operations. In 1975 this specific area was determined to be geologically unsuitable. 3 This determination was based on regional features of the Knox Group. Geologic data at the site have not been collected, and 
Table 3.12. Summary of results - overall ranking

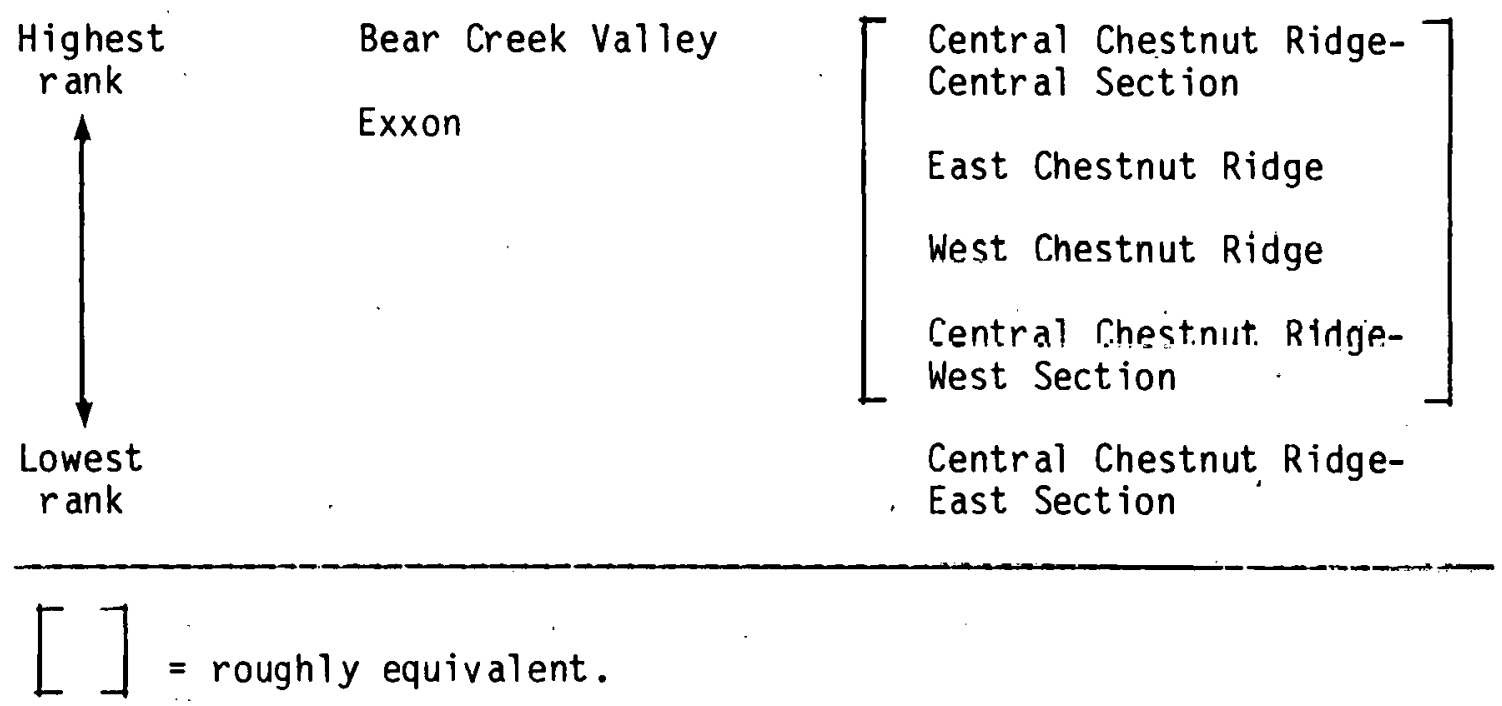

migration of contamination has not been detected (M. E. Mitchel1, ORGDP, Environmental Coordinator, personal communication to L. H. Stinton, UCC-NO Engineering, Nov, 15, 1982). Low-level waste disposal operations in the Rome formation have not been attempted to date. The interests of the developer in continuing disposal operations in the Conasauga Group in the future rather than initiating disposal operations in the knox Group have not been established at this time. Use of either the Conasauga or Knox Group for future disposal will depend on the results of ongoing technical studies and disposal requirements (J. D. Sease, Manager ORNL LLW research and development, personal communication to L. H. Stinton, UCC-NO Enginesring, Nov. 11, 198?,). The results of these investigations would permit the identification of a preferred site that is best suited to the needs of the developer and could satisfy the DOE site selection criteria. With the identification of the preferred site, site screening would be complete, and the site selection process would proceed to site characterization. 


\subsection{Comparison with Previous Studies}

The only available site selection study for a low-level radioactive waste disposal site on the Oak Ridge Reservation is contained in "Alternatives Document for the Oak Ridge Solid Waste Disposal Facilities Feasibility Study." 4 In general, the procedure followed consisted of establishing regulatory constraints on siting, and establishing institutional-operational requirements. The regulatory constraints and the institutional-operational requirements were modified to the extent necessary to permit successful application to the Oak Ridge Reservation. Consequently, the constraints were more site specific than the generic DOE site selection criteria.

The geologic units present on the reservation were evaluated in light of their general acceptability for low-level radioactive waste disposal. An exclusion process was used to identify suitable areas for solid waste disposal. The Conasauga Group was identified as the most favorable host unit based on the abundance of illite in the clays, the availability of hydrologic data for the Conasauga Group, and location requirements and engineering constraints. These requirements and constraints included maximum slope, permeability, and the presence of major fractures. The exclusion process identified three potential site areas for low-level radioactive waste disposal including two sites in Bear Creek Valley (the Exxon site and the Bear (reek Valley site) and the Melton Valley site. The study recomended use of the Central Chestnut Ridge sites for sanitary landfills and retrievable radiuactive waste storage. The Bear Creek Valley site was recomended for low-level radioactive waste disposal.

The conclusions reached by the application of the generic site selection methodology are similar to those of the previous study. The methodologies for applying the site selection criteria were different. The previous study did not identify candidate areas or a slate of candidate sites; nor did it comparatively rank the candidate sites to identify a preferred site. The previous study's method was exclusionary and gave equal emphasis to each site selection criteria. This technique can result in disqualification of a potential site that has several outstanding 
characteristics but has a deficiency included in the criteria that potentially could be overcome with an engineered design feature. For example, the Chestnut Ridge sites were excluded as potential sites because of the selection of the Conasauga Group for a host unit prior to identifying potential sites or investigating their characteristics. The selection of the Conasauga Group as the disposal unit was made on the basis of soil properties, the availability of hydrologic data, and the overall features of the Conasauga Group. The constraints on siting that were applied were much more flexible than the DUt criteria. Allowting regulalury requirements to be adaptcd to a predefined region can result. in the identification of a preferred site that is in violation of site selection criteria and protracted debate over the suitability of the site that is selected. As a result, the previous method for selecting a preferred site is difficult to defend.

The similarity of the conclusions in the present and previous studies suggests that the available technical information was similarly interpreted and applied. However, the present study separates exclusionary requirements from desirable features and evaluates the comparative merit of each site. Consequently, the basis for identifying a preferred site and excluding other candidate sites is apparent and well documented. 
1. W. M. McMaster, "Geologic Map of the Oak Ridge Area, Tennessee," Scale 1:31,680, USGS map, U.S. Geol. Survey, Reston, VA., 1962.

2. T. H. Hardin, et al., Oak Ridge Reservation Land-Use Plan, DOE/ORO-748 (Rev. 1) U.S. Dept. of Energy, Oak Ridge Operations, Dak Ridge, Tenn., 1980.

3. Department of Energy, Environmental Assessment of the Oak Ridge Gaseous Diffusion Plant Site, DOE/EA-0106, 1979.

4. P. N. Allen, et al., "Alternatives Document for the Oak Ridge Sol id Waste Disposal Facilities Feasibility Study," Oak Ridge National: Laboratory, Oak Ridge, Tenn., 1980 (unpublished report). 


\section{CONCLUSIONS AND RECOMMENDATIONS}

The evaluation of the application of the DOE site selection criteria provided insight into the usefulness of the criteria and their ease of application.: A methodology for applying the criteria to the Oak Ridge Reservation was prepared. The application of the criteria provided the basis for the conclusions and recommendations for future applications.

\subsection{Criteria Evaluation}

The DOE site selection criteria provide minimum technical guidelines to be met in low-level waste site selection. Adherence to these criteria in site selection would result in the identification of a site that could meet the performance objectives required of low-level waste disposal facilities. The site selection criteria encompass the important factors to be considered in site selection; however, they are subject to interpretation and provide no guidance as to how they should be applied to a specific region of interest.

The ease of application of the site selection criteria cannot be determined without consideration of the methodology used to select a site. Because of their generic nature, the criteria alone cannot be directly applied to site selection. Consequently, the development of a methodology is necessary for their effective application. The methodology developed for this study requires the development of regionally specific screening requirements to incorporate the site selection criteria in the identification of candidate areas, candidate sites, and a preferred site. The methodology applies the criteria in a clear, efficient, and logical manner so that the results are useful and defensible. The site selection criteria when coupled with the methodology that was developed were easily applied and would be adaptable to any region of interest.

The site selection criteria were made functional through the use of screening requirements, site selection parameters and regional significance of each selection parameter. These functional forms of the criteria need to be reconsidered for each site selection study. As 
functional forms of the site selection criteria, they are the dominant influence in identifying a preferred site. The most restrictive constraint in the use of the site selection criteria is the definition of the region of interest. While this definition is necessary, it lies outside the scope of the site selection criteria and can inhibit the identification of an obviously superior site. Therefore, definition of the region of interest should be made with a clear and defensible argument for its establishment.

The methodology used in this study utilized an adaptive framework for establishing site screening requirements and site selection parameters. An adaptive framework provides the additional flexibility required for considering the needs of the developer and alternative sites with varying degrees of site-specific data. This approach contrasts with the approach incorporated in data-intensive, site performance models for site screening. Existing performance assessment models which estimate radiation doses as specified in the performance objectives were not applied to the evaluation of the site selection criteria because the detailed, sitespecific data required for their application were not available. This limitation would exist for practically all site screening investigations.

\subsection{Application of DOE Site Selection Criteria}

This study indicates that the criteria are useful in their application to site selection and specifically in site screening. The application of the criteria to the Oak Ridge Reservation provided the necessary technical guidance in identifying site selection parameters that were comprehensive. They also highlighted the deficiencies of the natural characteristics of candidate sites that would require attention in the design of a low-level waste facility on the 0ak Ridge Reservation. The criteria provided the basis for making a defensible site selection when supplemented by a rational methodology capable of screening candidate sites. The criteria are biased towards the geohydrologic characteristics of the site. The results of this study indicate that this bias is appropriate and useful in selecting a site. 
Application of the DOE site selection criteria using the generic methodology was qualitative and required considerable judgment at each step. The screening requirements for identifying candidate areas and candidate sites were somewhat arbitrary. They included the site selection criteria along with other requirements reflecting the need to consider alternative sites and the needs of the developer. These screening requirements, the site selection parameters in Table 2.1, and the regional significance attached to the site selection parameters were the functional form of the DOE site selection criteria.

The definition of the region of interest was the most exclusionary step in the application of the site selection criteria. The definition of the Oak Ridge Reservation as the region of interest admitted only two viable geologic groups for consideration. Neither of these groups is an ideal geologic or hydrologic setting for low-level waste disposal. The site: selection criteria were applied in this context. As a result of the limited region of interest, the preferred sites that were identified may not satisfy all of the technical requirements in the site selection criteria without the incorporation of engineered design features or improved waste forms. The site selection criteria, however, do identify those deficiencies which require further consideration in the design of a facility at a preferred site: Additionally, the focus of site characterization activities is more sharply established by using the site selection criteria during site screening.

\subsection{Recommendations for Use of Generic Methodology}

The generic methodology used to apply the DOE site selection criteria provided a clear and defensible means for evaluating the use of the criteria. The methodology is sufficiently generic that its application to other regions of interest or with the NRC site selection criteria would be practical. Several recommendations concerning the application of the generic methodology are presented to assist in future site selection investigations. 
The candidate area identification utilizes somewhat arbitrary, exclusionary requirements for focusing the site screening process. The experience in applying these requirements suggests that they should be formulated with as great an emphasis as possible on the desirable physical features for the site. For most applications the physical features of significance are geologic and hydrologic. Placing early emphas is on institutional requirements for candidate area identification can result in the identification of candidate areas that are undesirable from a geologic and hydrologic perspective. Institutional requirements are subject to frequent changes in policy, but little can be done to significantly alter the geologic or hydrologic setting that will result in stable conditions for waste disposal.

Candidate site requirements should be formulated to include site-specific, exclusionary requirements that cannot be specified for area screening. The desirable features for candidate site screening should be selected so that the slate of candidate sites is sufficiently large for comparison but not so lengthy as to inhibit comparative analysis. Institutional requirements should be incorporated into the candidate site screening requirements.

The identification of a preferred site results from a subjective comparison of the slate of candidate sites with regard to the prepared 1 ist of site selection parameters. As was discussed in Sect. 2, the site selection parameters need to be based on the DOE site selection criteria and the regionally relevant factors influencing site performance and acceptability. The assignment of significance to each parameter and the parameters themselves largely influences the identification of a candidate site as the preferred site. This point cannot be over emphasized and should serve as an important consideration in preferred site 1dentification. Many site selection methodologies identify the preferred site using quantitative techniques. While these methóds are quantitative, they are not any more objective than qualitative methods. Quantitative techniques could be adapted to this methodology, but they are not recommended. Their application tends to obscure the subjective nature of the identification of a preferred site. 
The characterization of a preferred site is expensive and time consuming. Therefore, the steps in the methodology discussed in Sect. 2.2 represent an evolutionary process for most sites. Adaptation of the methodology for specific sites should be considered and is recomended for sites that are not easily characterized. The recommended process in the methodology is to encourage early interaction among the field investigation program, pathways analysis, and site design. The site feasibility investigation is intended to facilitate integration of these activities. By encouraging interaction of the field activities with the pathways analysis and site design, costs, delays in licensing, and delays in site development can be reduced. For sites that are especially difficult to characterize, several phases of site characterization may be appropriate to ensure site acceptability and effective site utilization.

\subsection{Conclusions}

The primary conclusions of this study are as follow:

- The DOE site selection criteria are useful in site selection and can be easily applied with the use of a rational methodology.

- Application of the DOE site selection criteria with the methodology developed in this study is qualitative and requires considerable judgment at each step in the process.

- Definition of the region of interest, development of the functional form of the site selection criteria as site screening requirements, and site selection parameters, and regional significance of the parameters are the dominant influences in the identification of a preferred site.

- The use of performance assessment computer models for site screening requires site-specific data that are generally not available. Additionally, these models are not well suited for considering the needs of the developer or alternative sites. 


\section{4-6}

- The generic methodology developed in this study is applicable to other regions of interest and could be used with other site selection criteria. 


\section{INTERNAL DISTRIBUTION}

1. H. G. Arnold

2. S. I. Auerbach

3. J. S. Baldwin

4. W. J. Boegly, Jr.

5. C. R. Boston

6. J. W. Boyle

7. G. F. Cada

8. R. A. Cantor

9. S. A. Carnes

10. R. 0. Chester

11. J. E. Christian

12. L. M. Cochran

13. E. D. Copenhaver

14. N. H. Cutshall

15. E. C. Davis

16. R. M. Davis

17. S. P. du Mont

18. M. K. Esserlieu

19. L. D. Eyman

20. D. E. Ferguson

21. D. E. Fields

22. R. B. Fitts

23. R. J. Friar

24. W. Fulkerson

25. C. C. Gilmore

26. R. W. Glass

27. T. Grizzard

28. C. S. Haase

29. B. A. Hannaford

30. F. E. Harrington

31. S. G. Hildebrand

32. E. L. Hillsman

33. D. D. Huff

34. M. T. Huie

35. D. B. Hunsaker, Jr.

36. D. W. Jones

37. R. H. Ketelle

38. E. M. King

39. J. T. Kitchings

40-44. D. W. Lee

45. R. Lee

46. T. F. Lomenick
47. W. E. Manrod

48. J. F. McBrayer

49. L. N. McCold

50-54. L. J. Mezga

55. M. E. Mitchell

56. M. S. Moran

57. J. M. Napier

58. T. W. Oakes

59. P. D. Parr

60. J. A. Parsons

61. E. Peele

62. C. H. Petrich

63. T. W. Pickel.

64. F. G. Pin

65. P. M. Pritz

66. R. M. Reed

67. D. E. Reichle

68. C. G. Rizy

69. R. D. Roop

70. E. R. Rothschild

71. T. H. Row

72. R. M. Rush

73. J. D. Sease

74. E. D. Smith

75. B. P. Spalding

76. W. P. Staub

77. E. 0. Sternberg

78. S. H. Stow

79-83. L. E. Stratton

84. J. Switek

85. T. Tamura

86. W. T. Thompson

87. D. J. Wilkes

88. T. J. Wilbanks

89. A. J. Witten

90. H. E. Zittel

91. ORNL Patent Office

92-93. Central Research Library

94. Document Reference Section

95-96. Laboratory Records Department

97. Laboratory Records - RC

\section{EXTERNAL DISTRIBUTION}

98. M. J. Barainca, U.S. DOE, Idaho Operations Office, 550 Second St., Idaho Falls, ID, 83401.

99. D. R. Brown, U.S. DOE, Oak Ridge Operations Office, P.O. Box E, Oak Ridge, TN, 37830. 
100. R. Eugene Goodson, Hoover Universal Inc., 135 E. Bennett St., P.0. Box 113, Saline, MI, 48176.

101-105. D. E. Large, U.S. DOE, Oak Ridge Operations Office, P.0. Box E, Oak Ridge, TN, 37830.

106-125. G. B. Levin, Low-Level. Waste Management, Willow Creek Building, EG\&G Idaho Inc., P.0. Box 1625, Idaho Falls, ID, 83415.

126. Todd R. LaPorte, Institute of Government Studies, University of California, 198 Moses Hall, Berkeley, CA, 94720.

127. Laurence I. Moss, 5769 Longs Peak Route, Estes Park, C0, 80517.

128. Milton Russe11, Resources for the Future, 1755 Massachusetts Avenue, NW, Washington, D.C., 20036.

129. William H. Williams, American Telephone and Telegraph, Building 53, Room 110, Murray $\mathrm{Hi} 11, \mathrm{NJ}, 07974$.

130. Office of Assistant Manager for Energy Research and Development, U.S. DOE, Oak Ridge Operations, P.0. Box E, Oak Ridge, TN, $37830^{\circ}$

131-248. Technical Information Center, P.0. Box 62, Oak Ridge, TiN, 37830 (Given distribution as shown in TIC-4500 under Category UC-70B, Organization Master Codes DA, DB, DD, 0 , and G). 